Prepared in cooperation with the Bureau of Reclamation

\title{
Estimation of Salt Loads for the Dolores River in the Paradox Valley, Colorado, 1980-2015
}

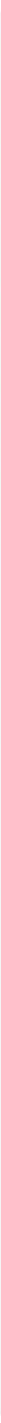

Scientific Investigations Report 2017-5059 


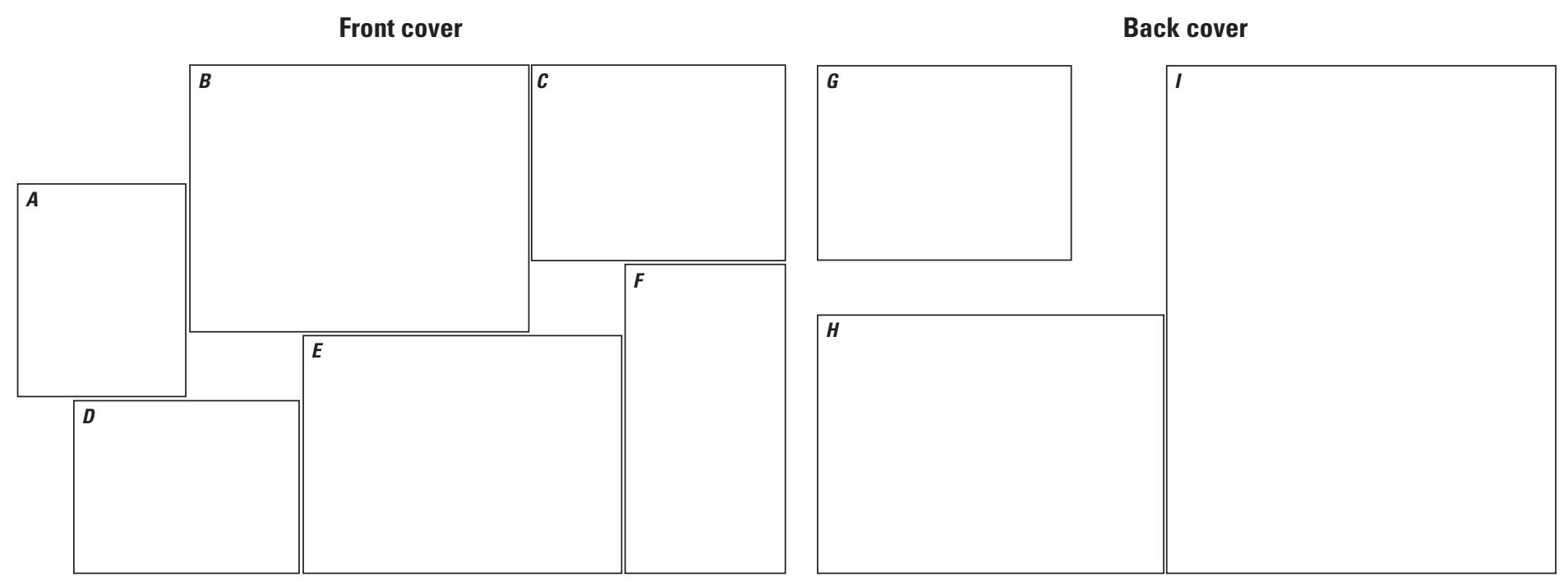

Cover photographs (front and back). A, E, Views of the Dolores River in the Paradox Valley, Colorado. B, G, U.S. Geological Survey streamgage 09169500, Dolores River at Bedrock, Colo. C, D, I, U.S. Geological Survey streamgage 09171100, Dolores River near Bedrock, Colo. $F, H$, Flow measurements being taken in winter at streamgage 09171100. 


\section{Estimation of Salt Loads for the Dolores River in the Paradox Valley, Colorado, 1980-2015}

By M. Alisa Mast

Prepared in cooperation with the Bureau of Reclamation

Scientific Investigations Report 2017-5059 


\title{
U.S. Department of the Interior \\ RYAN K. ZINKE, Secretary
}

\section{U.S. Geological Survey William H. Werkheiser, Acting Director}

\author{
U.S. Geological Survey, Reston, Virginia: 2017
}

For more information on the USGS - the Federal source for science about the Earth, its natural and living resources, natural hazards, and the environment-visit https://www.usgs.gov or call 1-888-ASK-USGS.

For an overview of USGS information products, including maps, imagery, and publications, visit https://store.usgs.gov/.

Any use of trade, firm, or product names is for descriptive purposes only and does not imply endorsement by the U.S. Government.

Although this information product, for the most part, is in the public domain, it also may contain copyrighted materials as noted in the text. Permission to reproduce copyrighted items must be secured from the copyright owner.

Suggested citation:

Mast, M.A., 2017, Estimation of salt loads for the Dolores River in the Paradox Valley, Colorado, 1980-2015: U.S.

Geological Survey Scientific Investigations Report 2017-5059, 20 p., https://doi.org/10.3133/sir20175059.

ISSN 2328-0328 (online) 


\section{Contents}

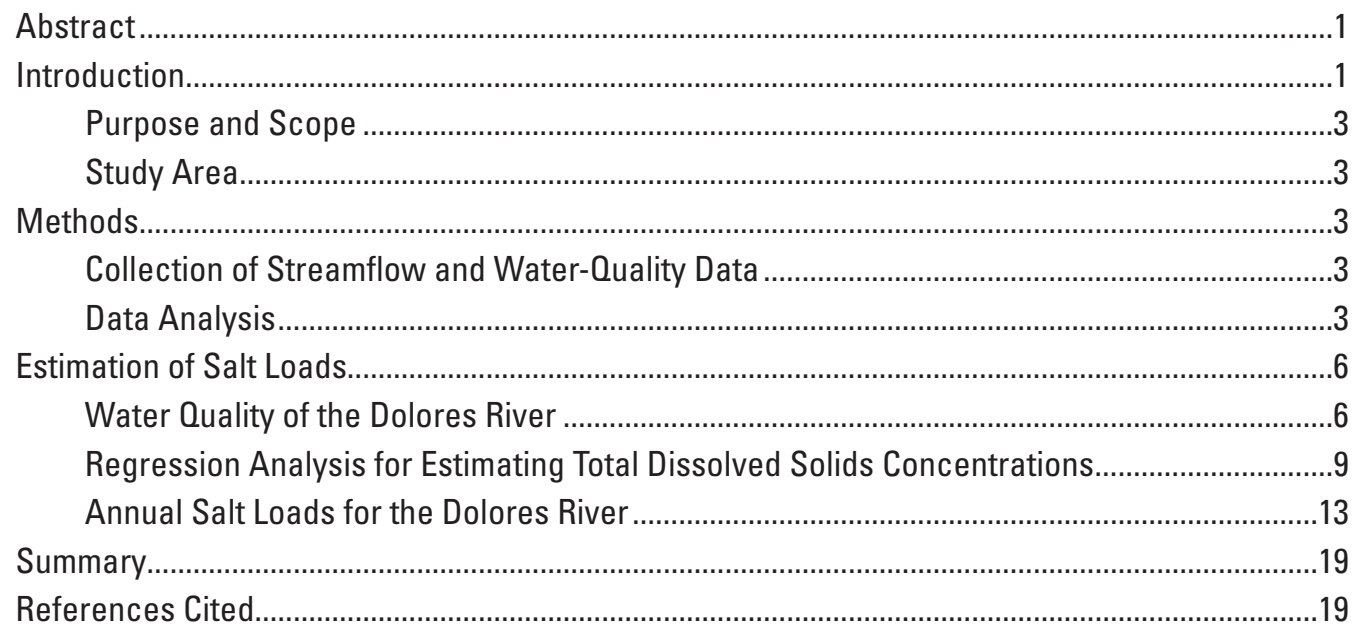

\section{Figures}

1. Map of the Paradox Valley and the Dolores River showing locations of U.S. Geological Survey streamgages and Paradox Valley Unit production wells

2. Measured and estimated daily specific-conductance values for the Dolores River at Bedrock site and the Dolores River near Bedrock site for 1980-2015 ...........................5

3. Specific-conductance survey of the Dolores River through the Paradox Valley conducted by the Bureau of Reclamation on June 24-25, 2013

4. Boxplots comparing discharge, specific conductance, and major-ion concentrations in water-quality samples collected at the Dolores River at Bedrock site and the Dolores River near Bedrock site

5. Specific conductance versus total dissolved solids concentrations in 252 water-quality samples collected at the Dolores River near Bedrock site during 1987-2015.

6. Predicted versus residual total dissolved solids concentrations using model 3 for the Dolores near Bedrock site and model 5 for the Dolores at Bedrock site

7. Specific conductance versus total dissolved solids concentrations for the Dolores River at Bedrock site

8. Comparison of slope and y-intercept resulting from linear fit of total dissolved solids concentrations with specific conductance for the Dolores River at Bedrock site and the Dolores River near Bedrock site for periods before and after operation of the Paradox Valley Unit began.

9. Daily salt gain with measurement uncertainty for the Dolores River through the Paradox Valley during 2015

10. Annual salt gain in the Dolores River through the Paradox Valley with error bars showing measurement uncertainty for periods before and after operation of the Paradox Valley Unit began

11. Annual mean discharge at the Dolores River near Bedrock site for periods before and after operation of the Paradox Valley Unit began with the annual Palmer Drought Index for the upper Colorado River Basin.. 
12. Annual mean discharge at the Dolores River near Bedrock site versus annual salt gain for periods before and after operation of the Paradox Valley Unit began

13. Annual mean discharge versus volume-weighted mean total dissolved solids concentrations for the Dolores River near Bedrock site for periods before and after operation of the Paradox Valley Unit began.....

14. Annual salt gain in the Dolores River during 1980-2015 ................................................18

\section{Tables}

1. Specific-conductance data collected by the Bureau of Reclamation during a synoptic survey of the Dolores River through the Paradox Valley conducted on July 24-25, 2013

2. Parameters and coefficients of determination of regression models used to estimate total dissolved solids concentrations from specific conductance for the Dolores River at Bedrock site and the Dolores River near Bedrock site

3. Annual salt removal by the Paradox Valley Unit, salt loads with uncertainty estimates for the Dolores River at Bedrock site and the Dolores River near Bedrock site, and net salt gain through the Paradox Valley for 1980-2015.

4. Comparison of mean annual salt gain in tons per year in the Dolores River through the Paradox Valley before and after operation of the Paradox Valley Unit began.

\section{Conversion Factors}

U.S. customary units to International System of Units

\begin{tabular}{lll}
\hline \multicolumn{1}{c}{ Multiply } & By & \multicolumn{1}{c}{ To obtain } \\
\hline inch (in.) & Length & \\
foot $(\mathrm{ft})$ & 2.54 & centimeter $(\mathrm{cm})$ \\
mile $(\mathrm{mi})$ & 0.3048 & meter $(\mathrm{m})$ \\
\hline & 1.609 & kilometer $(\mathrm{km})$ \\
\hline square mile $\left(\mathrm{mi}^{2}\right)$ & Area & \\
\hline & 2.590 & square kilometer $\left(\mathrm{km}^{2}\right)$ \\
\hline cubic foot per second $\left(\mathrm{ft}^{3} / \mathrm{s}\right)$ & Flow rate & \\
\hline & 0.02832 & cubic meter per second $\left(\mathrm{m}^{3} / \mathrm{s}\right)$ \\
\hline ton, short $(2,000 \mathrm{lb})$ & Mass & \\
\hline
\end{tabular}

International System of Units to U.S. customary units

\begin{tabular}{lcl}
\hline Multiply & By & To obtain \\
\hline & Length & \\
\hline centimeter $(\mathrm{cm})$ & 0.3937 & inch (in.) \\
\hline liter $(\mathrm{L})$ & Volume & \\
\hline & 33.81402 & ounce, fluid (fl. oz) \\
\hline gram $(\mathrm{g})$ & Mass & \\
\hline & 0.03527 & ounce, avoirdupois $(\mathrm{oz})$ \\
\hline gram per cubic centimeter $\left(\mathrm{g} / \mathrm{cm}^{3}\right)$ & Density & \\
\hline
\end{tabular}




\section{Supplemental Information}

Specific conductance is given in microsiemens per centimeter at 25 degrees Celsius $\left(\mu \mathrm{S} / \mathrm{cm}\right.$ at $\left.25^{\circ} \mathrm{C}\right)$.

Concentrations of total dissolved solids and chemical constituents in water are given in milligrams per liter (mg/L).

\section{Abbreviations}

$\begin{array}{ll}\text { Reclamation } & \text { Bureau of Reclamation } \\ \text { PVU } & \text { Paradox Valley Unit } \\ \mathrm{R}^{2} & \text { coefficient of determination } \\ \text { SC } & \text { specific conductance } \\ \text { TDS } & \text { total dissolved solids } \\ \text { USGS } & \text { U.S. Geological Survey } \\ \text { VWM } & \text { volume-weighted mean }\end{array}$





\title{
Estimation of Salt Loads for the Dolores River in the Paradox Valley, Colorado, 1980-2015
}

\author{
By M. Alisa Mast
}

\section{Abstract}

Regression models that relate total dissolved solids (TDS) concentrations to specific conductance were used to estimate salt loads for two sites on the Dolores River in the Paradox Valley in western Colorado. The salt-load estimates will be used by the Bureau of Reclamation to evaluate salt loading to the river coming from the Paradox Valley and the effect of the Paradox Valley Unit (PVU), a project designed to reduce the salinity of the Colorado River. A second-order polynomial provided the best fit of the discrete data for both sites on the river. The largest bias occurred in samples with elevated sulfate concentrations (greater than 500 milligrams per liter), which were associated with short-duration runoff events in late summer and fall. Comparison of regression models from a period of time before operation began at the PVU and three periods after operation began suggests the relation between TDS and specific conductance has not changed over time. Net salt gain through the Paradox Valley was estimated as the TDS load at the downstream site minus the load at the upstream site. The mean annual salt gain was 137,900 tons per year prior to operation of the PVU (1980-1993) and 43,300 tons per year after the PVU began operation (1997-2015). The difference in annual salt gain in the river between the pre-PVU and post-PVU periods was 94,600 tons per year, which represents a nearly 70 percent reduction in salt loading to the river.

\section{Introduction}

The Paradox Valley is a topographic basin approximately 25 miles (mi) long and 3-5 mi wide located in western Colorado (fig. 1). The valley is a collapsed salt anticline that formed by the upward flow of salts (gypsum, anhydrite, and halite) from the deeply buried Pennsylvanian Paradox Formation (Cater, 1970). The salts were subsequently dissolved, which caused the overlying bedrock to collapse, thereby forming an elongated valley along the northwest to southeast trend of the underlying anticline. The Dolores River, a major tributary of the Colorado River, crosses the Paradox Valley perpendicular to and about midway along the axis of the valley, entering and leaving through canyons incised through as much as 1,000 feet (ft) of Paleozoic and Mesozoic rocks. On the valley floor, Quaternary alluvial deposits occur along the Dolores River and consist of layers of sand, gravel, and clay that form a water-table alluvial aquifer with a total thickness of up to $170 \mathrm{ft}$ (Bureau of Reclamation, 1978). In the center of the valley, the alluvial aquifer overlies the Paradox Formation where the core of the Paradox Valley anticline and the saltbearing Paradox Formation are closest to the land surface (Ball and others, 2015). Salt in the Paradox Formation is dissolved by regional groundwater flow that upwells through a brecciated zone at the top of the Paradox and into the alluvial aquifer (Bureau of Reclamation, 1978). Because the brine has a density of nearly 1.2 grams per cubic centimeter, water in the alluvial aquifer is stratified, containing a dense brine layer overlain by a layer of freshwater developed from surficial recharge. The freshwater layer thickens in spring and summer months in response to snowmelt runoff, irrigation return flows, and associated water management in the valley and thins (drains) during winter when recharge from these sources diminishes. Salt concentrations below the freshwater-brine interface have been measured in excess of 250,000 milligrams per liter (mg/L) (Watts, 2000). In the vicinity of the river, where the freshwater-brine interface is very close to the surface, brine discharges through the streambed into the Dolores River. During low-flow conditions in fall and winter, when freshwater recharge is minimal, brine discharge causes salinity concentrations in the river to increase by over three orders of magnitude as it flows across the valley floor.

The Paradox Valley Unit (PVU), which is located in the center of the Paradox Valley adjacent to the Dolores River, is a salinity-control project authorized under the Colorado River Basin Salinity Control Act of 1974 (Public Law 93-320, amended in 1984 as Public Law 98-569) and operated by the Bureau of Reclamation (http:/www.usbr.gov/uc/wcao/progact/ paradox/). The PVU consists of nine production wells, a collection facility, and one injection well that were constructed in the late 1980s to reduce the salinity of the Colorado River, which is a major concern for downstream municipal, industrial, and agricultural water use. The PVU production wells, which are located adjacent to the river (fig. 1), are completed near the base of the alluvial aquifer below the freshwater-brine interface. Withdrawal of brine through production wells reduces brine discharge from the shallow groundwater system into the river, thus reducing the salinity of the river where it exits the valley. Brine is withdrawn from the production wells at a total rate of about 0.5 cubic feet per second $\left(\mathrm{ft}^{3} / \mathrm{s}\right)$ and disposed of through a 


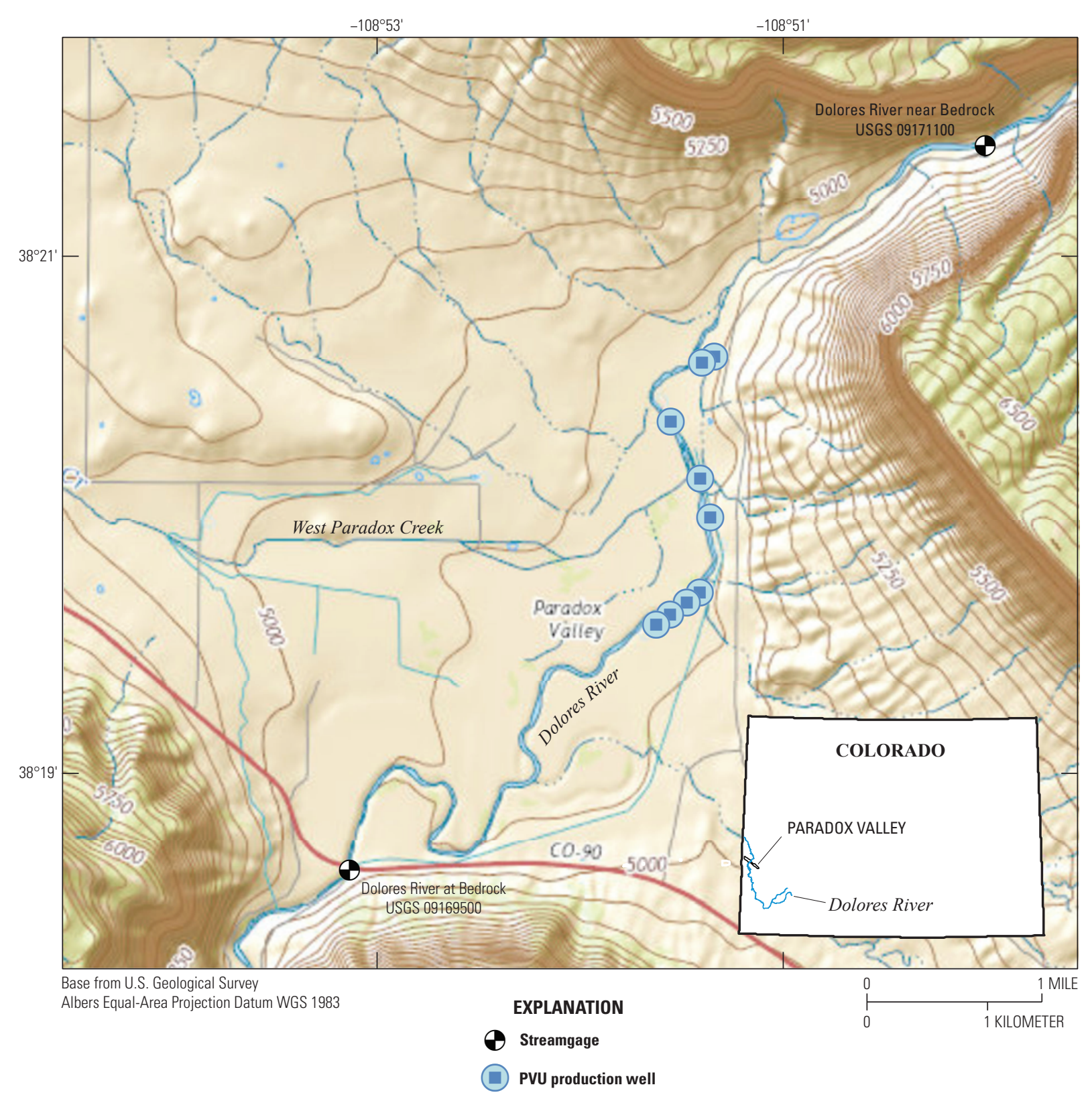

Figure 1. Map of the Paradox Valley and the Dolores River showing locations of U.S. Geological Survey (USGS) streamgages and Paradox Valley Unit (PVU) production wells.

16,000 -ft-deep injection well located near the edge of the valley. Testing of the injection well occurred during 1991-1995, and regular operation of the PVU began in July 1996.

The Bureau of Reclamation (Reclamation) evaluates the effect of the PVU on salt loading to the river based on differences between the total dissolved solids (TDS) loads computed at two U.S. Geological Survey (USGS) streamgages on the Dolores River. The Dolores River at Bedrock site (USGS station 09169500) is located upstream from the PVU production wells where the river enters the valley, and the Dolores River near Bedrock site (USGS station 09171100) is located downstream from the PVU where the river exits the valley (fig. 1). Loads are computed on the basis of continuous measurements (15-minute interval) of specific conductance (SC) and discharge at the two USGS streamgages and monthly water-quality samples, which are used to develop regressions between TDS concentrations and SC. The USGS periodically assists Reclamation with updating the regressions and saltload estimates as new data become available. The two most recent USGS publications were authored by Chafin (2003), who developed regression models and computed daily salt loads for January 1988 through September 2001, and Linard and Schaffrath (2014), who developed regression models for October 2009 through September 2012. 


\section{Purpose and Scope}

This report documents and updates regression models developed to relate TDS concentrations to SC for the Dolores River at Bedrock site (USGS station 09169500) and the Dolores River near Bedrock site (USGS station 09171100) using available data through 2015. These results will be used to update the regression equations reported on the USGS National RealTime Water Quality website (http://nrtwq.usgs.gov/), which were originally published by Linard and Schaffrath (2014). The regressions are applied to daily records of SC to estimate the annual gain in salt load to the river as it flows across the Paradox Valley for 1980-2015. Available data-quality information is used to quantify uncertainties in annual salt loads. Annual salt gains are compared between a time period before routine operation of the PVU began (1987-1993; pre-PVU) and three time periods after operation began (1997-2015, 1997-2006, and 2007-2015; post-PVU). Reductions in annual salt load to the river during the post-PVU period are compared to annual salt disposal rates at the PVU injection well.

\section{Study Area}

The Dolores River originates in the San Juan Mountains southeast of the study area and drains a 2,024-square-mile $\left(\mathrm{mi}^{2}\right)$ area upstream from the Paradox Valley. Flow in the Dolores River is largely derived from snowmelt runoff at higher elevations and has been regulated by releases from McPhee Reservoir (90 mi upstream) since March 19, 1984 (Bureau of Reclamation, 1997). Climate on the floor of the Paradox Valley is semiarid, with mean annual precipitation of about 12 inches per year. Major land uses in the valley include rangeland and about 2,700 acres of irrigated cropland and pasture located northwest of the river. Surface water diverted from West Paradox Creek, the only perennial tributary in the valley, and the Dolores River are the primary sources of irrigation water.

\section{Methods}

\section{Collection of Streamflow and Water-Quality Data}

Streamflow and water-quality data used in this analysis were collected at two sites with USGS streamgages in Colorado: the Dolores River at Bedrock site (USGS station 09169500), herein referred to as the upstream site, and the Dolores River near Bedrock site (USGS station 09171100), herein referred to as the downstream site (fig. 1). Streamflow has been measured continuously at the upstream site since 1918 and at the downstream site since 1971. The streamgage at the upstream site has been operated at the same location over the entire period of record. The streamgage at the downstream site, however, was moved in 1972 to a location $200 \mathrm{ft}$ downstream from its original location and again in August 2000 approximately $600 \mathrm{ft}$ upstream to its current location.
Instream monitors that measure SC and water temperature at 15-minute intervals have been operated at each site starting in 1979. The SC monitor at the downstream site was located 1.2 mi upstream from the streamgage during 1980-1987 and in December 1987 was moved downstream to the current streamgage location. The SC monitor at the upstream site was located $150 \mathrm{ft}$ upstream from the streamgage during 1980-1989 and in July 1989 was moved downstream to the current streamgage location. Instream SC was measured using a USGS mini-monitor (Katzenbach, 1990) prior to winter 1994, a Hydrolab Reporter from winter 1994 to summer 2008, and a YSI 600 series sonde from summer 2008 to present (2015). Because water-quality monitors during all three time periods were operated according to standard USGS protocols (Wagner and others, 2006), and because field, laboratory, and instream SC sensor values agree over the entire period of record, measurements among the three different monitor types are comparable. Daily mean and unit-value (15-minute data) discharge and SC data were retrieved from the USGS National Water Information System (U.S. Geological Survey, 2015). Daily values are available for the entire period of record, and unit values are available starting in 1990.

Water-quality samples were collected at each streamgage by USGS personnel on a monthly schedule and cover a range of streamflow conditions. All samples were collected according to USGS National Field Manual protocol (U.S. Geological Survey, variously dated) and were analyzed at the National Water Quality Laboratory using approved methods (Fishman and Friedman, 1989). Available water-quality data for each streamgage were downloaded from the USGS National Water Information System (U.S. Geological Survey, 2015) including field parameters ( $\mathrm{SC}$, water temperature, $\mathrm{pH}$, dissolved oxygen, and alkalinity), major-ion concentrations, and computed TDS for samples with complete major-ion analyses. During the period 1987-2015, 252 samples with TDS and SC were retrieved at the downstream site, and 257 samples were retrieved at the upstream site. In a few cases, the laboratory $\mathrm{SC}$ was substituted for the field SC because the field value was either missing or suspect.

\section{Data Analysis}

All available unit-value (15 minutes) and daily-value data for discharge and SC at both the upstream and downstream sites for 1980 to 2015 were loaded into the Aquarius ${ }^{\circledR}$ software package (http://aquaticinformatics.com/products/), which was used to estimate periods of missing record and to perform load computations. Approximately 9 percent of the daily SC values from each site were missing because of sensor malfunctions, sensor fouling, or power failures. Short gaps (less than 72 hours) in the daily-value SC records were filled by linear interpolation. Longer gaps were filled using tools in Aquarius that build models based on surrogate signals such as discharge or SC at nearby sites to perform corrections on time-series data. Data from 1986 and 1987 were omitted from the analysis because 46 and 92 percent, respectively, of the SC 
records at the downstream site were missing for those years. The complete record of daily SC values showing periods of estimated record are shown in figure 2.

The discrete water-quality samples at each site were used to develop regression models for predicting daily TDS from the daily SC record. Version 3.2.3 of the R Stats package in the $\mathrm{R}$ software environment (https://stat.ethz.ch/R-manual/R-devel/ library/stats/) was used to generate regression statistics and residual plots that aid decisions about model adequacy (Helsel and Hirsch, 2002). Regression models were computed for the entire period of record (1980-2015) as well as for shorter periods including the pre-PVU period (1987-1993) and three different post-PVU periods (1997-2015, 1997-2006, and 2007-2015). The best-fitting regression model was used to estimate daily mean TDS concentrations at each stream site, and daily loads were computed as the product of daily mean discharge (in cubic feet per second), daily mean TDS (in milligrams per liter), and a conversion factor of 0.0026969 to yield results in tons per day. Daily loads were summed over calendar years to yield annual salt loads for each stream site from 1980 to 2015.

Uncertainties in the annual salt loads were quantified to the extent possible with available data-quality information. The measurement uncertainties of daily-discharge values were based on data-quality ratings (excellent, good, fair, poor, or estimated) that are published in annual data reports available at https://wdr. water.usgs.gov/. Data-quality ratings for the SC records were computed by a script that assigns ratings based on data corrections made to the raw $\mathrm{SC}$ records using guidance from Wagner and others (2006). The data-quality rating for each daily value was converted to a numeric uncertainty by assigning an uncertainty of \pm 2.5 percent to a rating of excellent, an uncertainty of \pm 5.0 percent to a rating of good, an uncertainty of \pm 7.5 percent to a rating of fair, and an uncertainty of \pm 15.0 percent to a rating of poor and to estimated records (Novak, 1985). Because the confidence intervals for the regression models were small compared to the measurement errors in SC, the TDS uncertainty was assumed equal to the $\mathrm{SC}$ uncertainty. The uncertainty of the daily load ( $\delta D L o a d)$, in tons per day, was then computed using the standard error propagation formula (Taylor, 1997),

$$
\delta \text { Dload }=\text { Dload } \times \sqrt{\left(\frac{\delta T D S}{T D S}\right)^{2}+\left(\frac{\delta Q}{Q}\right)^{2}}
$$

where Dload is the daily load, in tons per day; $\delta T D S$ is the uncertainty in daily TDS, in milligrams per liter; and $\delta Q$ is the uncertainty in the daily discharge $(Q)$, both variables in cubic feet per second. The daily uncertainties were summed over the year to yield the uncertainty for the annual salt load. These calculations assume that for aggregated uncertainties (such as annual load), systematic errors act in an additive manner, whereas random errors tend to cancel out over longer time scales (Moncrieff and others, 1996).

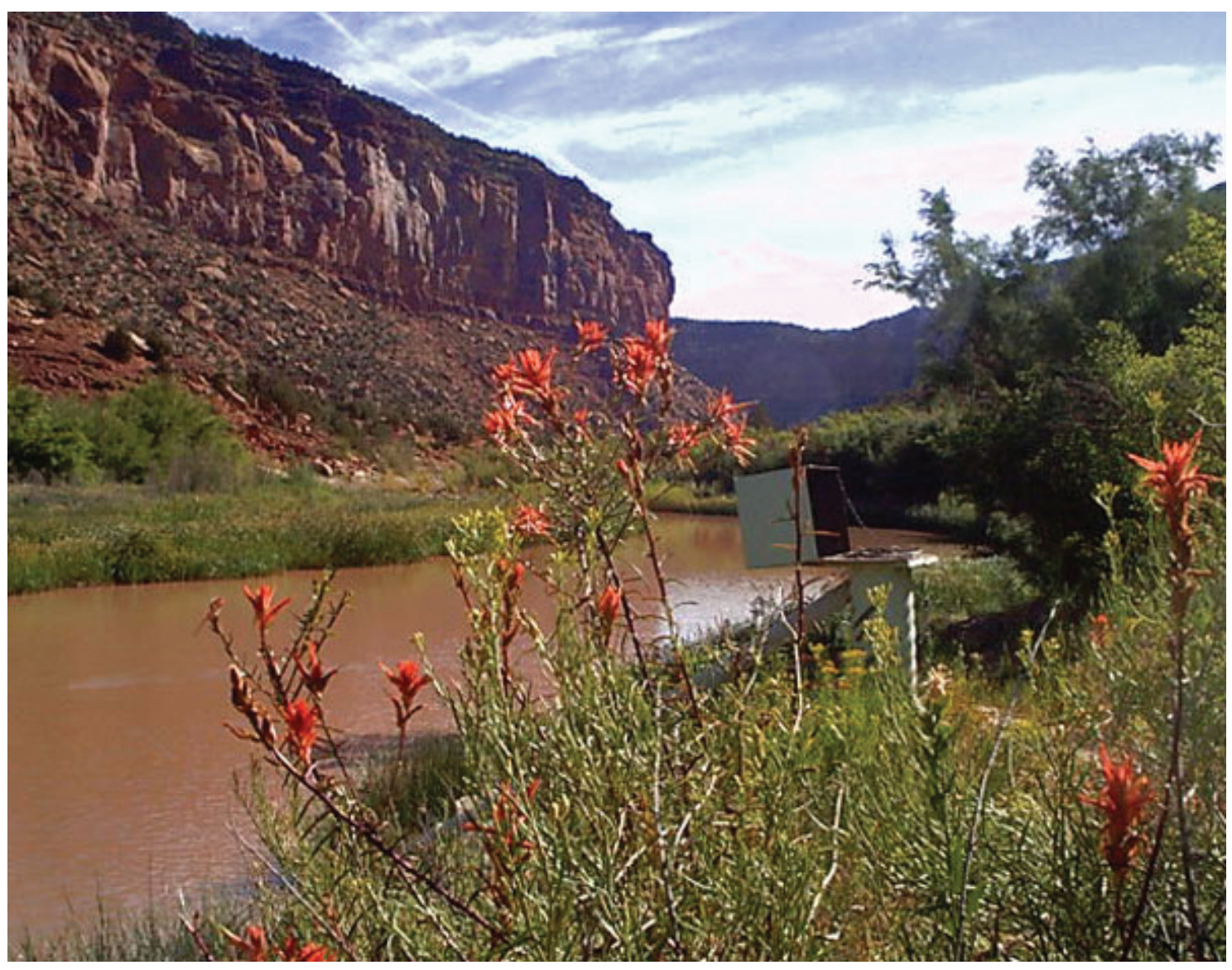


Dolores River at Bedrock (upstream site)

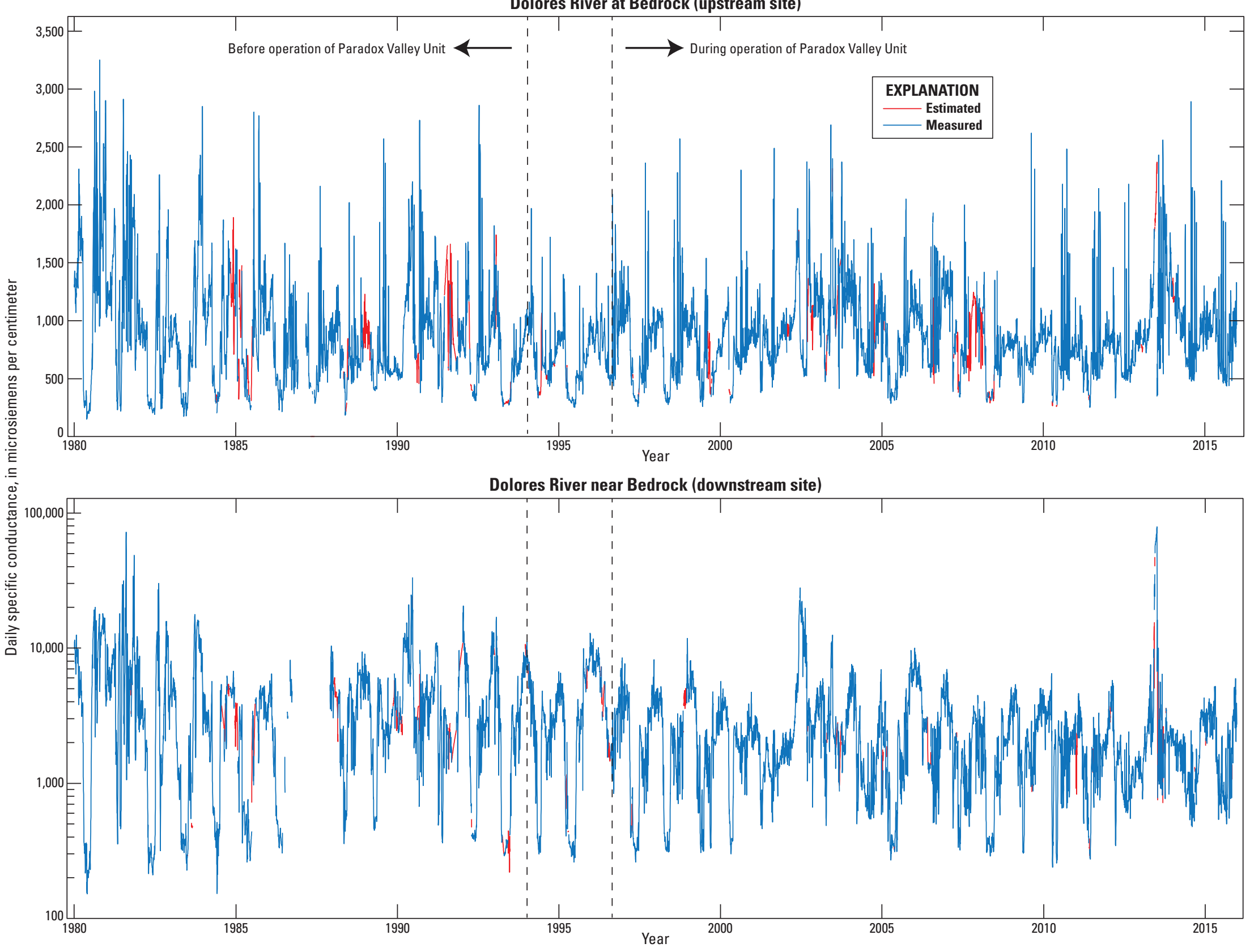

Figure 2. Measured and estimated daily specific-conductance values for the Dolores River at Bedrock site (upstream site) and the Dolores River near Bedrock site (downstream site) for 1980-2015. 


\section{Estimation of Salt Loads}

\section{Water Quality of the Dolores River}

The water quality of the Dolores River changes considerably as it crosses the Paradox Valley because naturally saline groundwater discharges into the river. A synoptic survey of $\mathrm{SC}$ in the river between the upstream and downstream sites illustrates the magnitude and spatial variability of water quality in the river across the valley (fig. 3). The SC survey was conducted by Reclamation in June 2013 (table 1) during an extremely dry period when SC values in the river were much greater than normal, accentuating the influence of brine discharge on the water quality of the river. At the upstream site where the river enters the valley, the SC was 1,990 microsiemens per centimeter $(\mu \mathrm{S} / \mathrm{cm})$ and increased to $31,000 \mu \mathrm{S} / \mathrm{cm}$ about $2 \mathrm{mi}$ downstream where salty

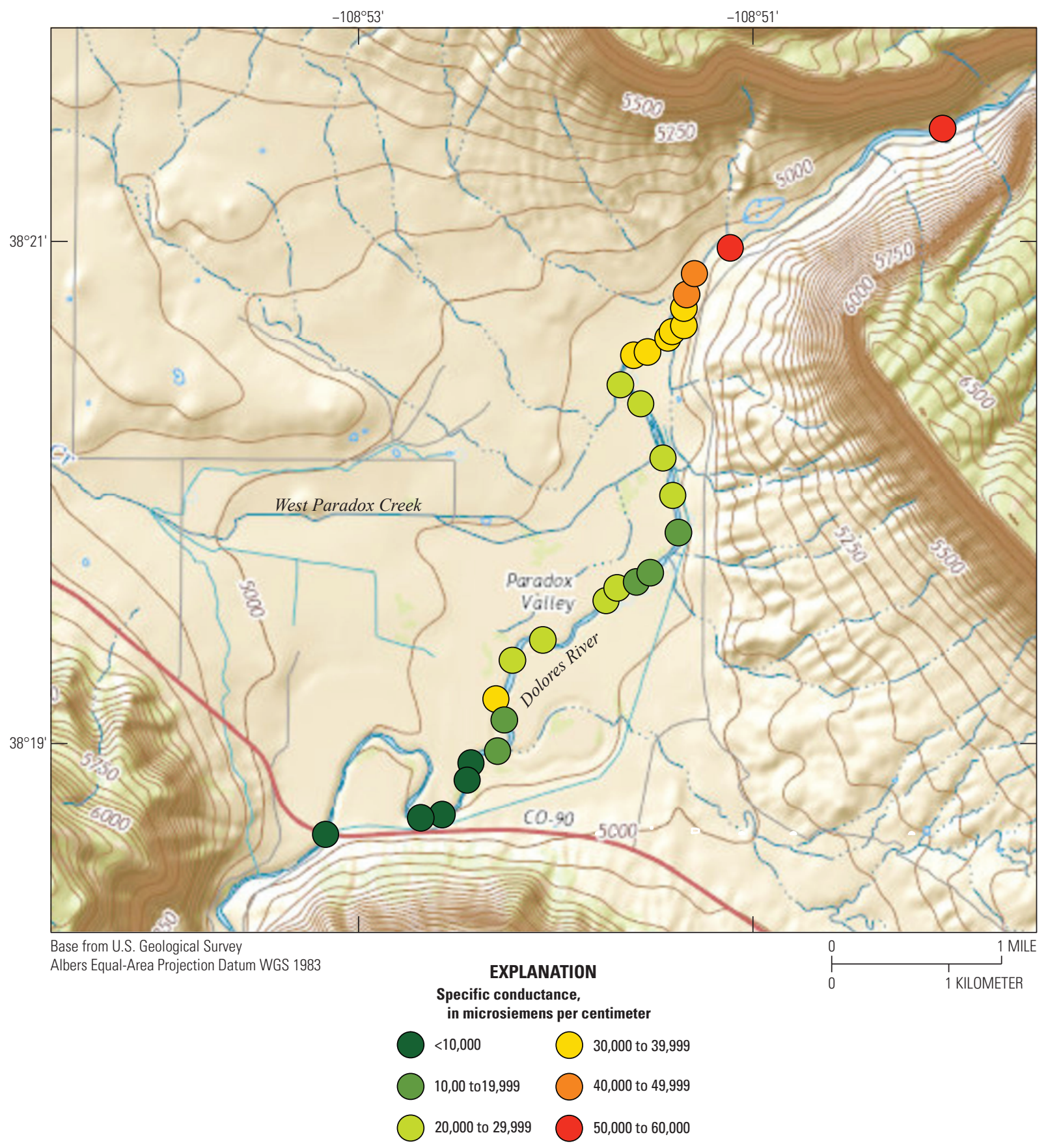

Figure 3. Specific-conductance survey of the Dolores River through the Paradox Valley conducted by the Bureau of Reclamation on June 24-25, 2013. Data shown in table 1. 
Table 1. Specific-conductance data collected by the Bureau of Reclamation during a synoptic survey of the Dolores River through the Paradox Valley conducted on July 24-25, 2013.

[Spec. cond., specific conductance in microsiemens per centimeter; date in M/DD/YYYY format; coordinate datum World Geodetic System 1984 (WGS-84)]

\begin{tabular}{|c|c|c|c|}
\hline Date & Latitude & Longitude & Spec. cond. \\
\hline $6 / 25 / 2013$ & 38.31050 & -108.88577 & 1,990 \\
\hline $6 / 24 / 2013$ & 38.31160 & -108.87773 & 4,310 \\
\hline $6 / 24 / 2013$ & 38.31180 & -108.87588 & 5,540 \\
\hline $6 / 24 / 2013$ & 38.31410 & -108.87375 & 4,450 \\
\hline $6 / 24 / 2013$ & 38.31525 & -108.87343 & 9,740 \\
\hline $6 / 24 / 2013$ & 38.31603 & -108.87122 & 11,120 \\
\hline $6 / 24 / 2013$ & 38.31807 & -108.87065 & 16,000 \\
\hline $6 / 24 / 2013$ & 38.31950 & -108.87133 & 31,000 \\
\hline $6 / 24 / 2013$ & 38.32205 & -108.86997 & 22,200 \\
\hline $6 / 25 / 2013$ & 38.32340 & -108.86740 & 23,700 \\
\hline $6 / 25 / 2013$ & 38.32598 & -108.86200 & 22,800 \\
\hline $6 / 25 / 2013$ & 38.32687 & -108.86108 & 21,500 \\
\hline $6 / 25 / 2013$ & 38.32725 & -108.85947 & 19,790 \\
\hline $6 / 25 / 2013$ & 38.32787 & -108.85828 & 19,050 \\
\hline $6 / 25 / 2013$ & 38.33045 & -108.85628 & 19,400 \\
\hline $6 / 25 / 2013$ & 38.33298 & -108.85638 & 20,200 \\
\hline $6 / 25 / 2013$ & 38.33548 & -108.85718 & 20,000 \\
\hline $6 / 25 / 2013$ & 38.33905 & -108.85910 & 23,200 \\
\hline $6 / 25 / 2013$ & 38.34033 & -108.86083 & 28,000 \\
\hline $6 / 25 / 2013$ & 38.34232 & -108.85970 & 32,700 \\
\hline $6 / 25 / 2013$ & 38.34253 & -108.85855 & 33,800 \\
\hline $6 / 25 / 2013$ & 38.34343 & -108.85680 & 34,900 \\
\hline $6 / 25 / 2013$ & 38.34387 & -108.85642 & 35,000 \\
\hline $6 / 25 / 2013$ & 38.34423 & -108.85545 & 37,500 \\
\hline $6 / 25 / 2013$ & 38.34545 & -108.85548 & 39,900 \\
\hline $6 / 25 / 2013$ & 38.34633 & -108.85522 & 43,000 \\
\hline $6 / 25 / 2013$ & 38.34772 & -108.85455 & 49,800 \\
\hline $6 / 25 / 2013$ & 38.34943 & -108.85152 & 52,100 \\
\hline $6 / 25 / 2013$ & 38.33045 & -108.85628 & 60,000 \\
\hline
\end{tabular}

groundwater likely discharged into the river. Where the river flows past the upper PVU well field, the SC decreased to about $20,000 \mu \mathrm{S} / \mathrm{cm}$, likely because fresher groundwater discharges into this reach of the river. Downstream from the lower end of the well field, the SC in the river increased to $60,000 \mu \mathrm{S} / \mathrm{cm}$ (over 30 times greater than at the upstream site) because of additional brine discharge from the alluvial aquifer.

In addition to spatial variability, the river also shows strong seasonal changes in the proportions of major cations and anions as a result of groundwater and surface-water interactions. Figure 4 shows data for the pre-PVU period in order to better illustrate the influence of brine discharge on water quality of the river. During April through June, when streamflow is relatively high, concentrations at the downstream site approach those at the upstream site, where the river is a mixed calcium-sodium-sulfate-bicarbonate-type water. During July through March, when streamflow is relatively low, the downstream site is dominated by sodium and chloride because of the greater influence of brine discharge at low flows.

Ranges of sulfate and calcium concentrations are fairly similar between the two sites during most months, suggesting that upstream sources as well as brine discharge contribute these solutes. Tuttle and Grauch (2009) used stable sulfur isotopes to show that sulfate in the Dolores River is derived from the dissolution of gypsum in the Mancos Shale and other sedimentary rocks upstream from the Paradox Valley as well as from anhydrite in the Paradox Formation. In fact, some of the greatest sulfate concentrations (greater than $800 \mathrm{mg} / \mathrm{L}$ ) occurred during late summer and fall storm events related to monsoonal weather patterns. During these storm events, sulfate concentrations were elevated at both stream sites, suggesting that sulfate under these hydrologic conditions is largely derived from areas upstream from the Paradox Valley.

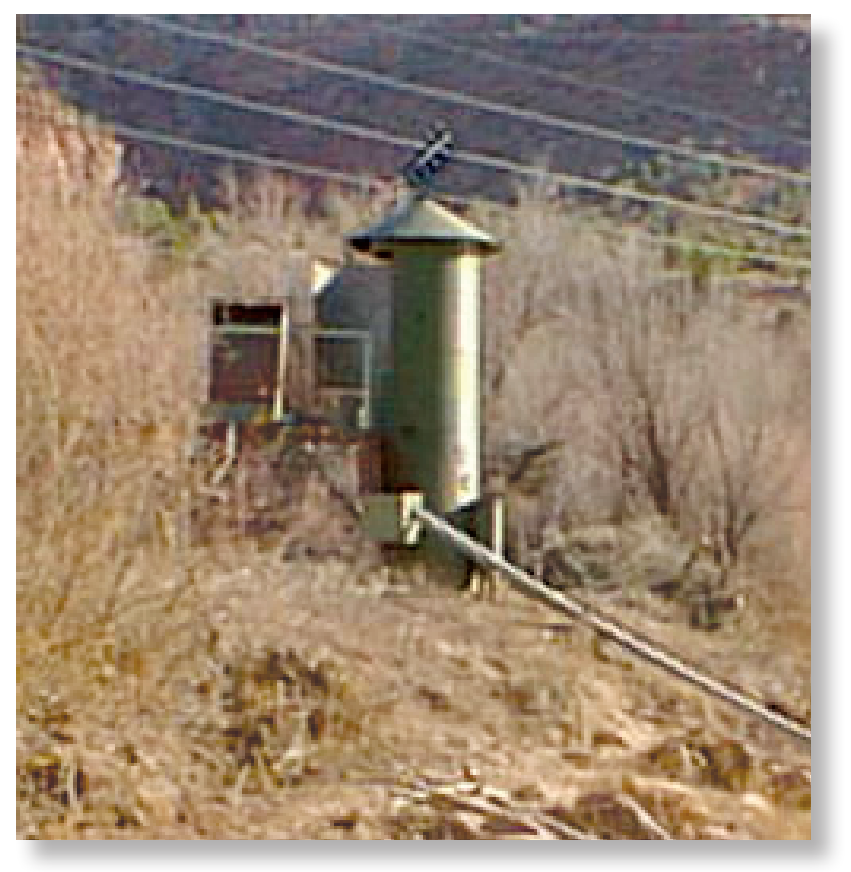



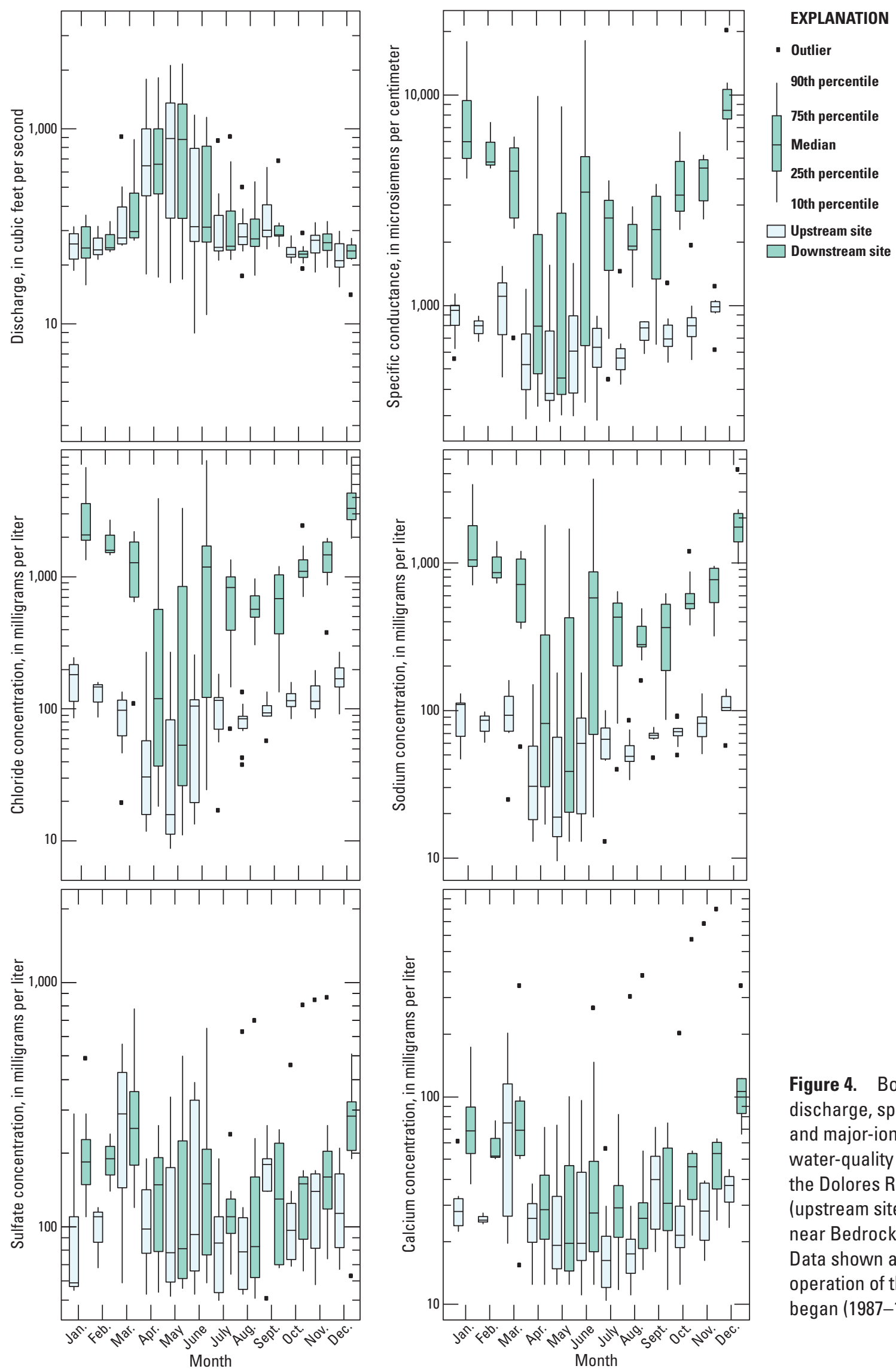

Figure 4. Boxplots comparing discharge, specific conductance, and major-ion concentrations in water-quality samples collected at the Dolores River at Bedrock site (upstream site) and the Dolores River near Bedrock site (downstream site). Data shown are for the period before operation of the Paradox Valley Unit began (1987-1993). 


\section{Regression Analysis for Estimating Total Dissolved Solids Concentrations}

Regression models were developed using TDS and SC measured in discrete water-quality samples collected from 1987 to 2015; coefficients and statistics for the models are presented in table 2. Initially, all samples at the downstream site were included in a linear model (table 2, model 1); however, a sample collected on July 10, 2013, with an unusually high SC $(78,540 \mu \mathrm{S} / \mathrm{cm})$ leveraged the regression line upward (Cook's Distance $=0.65$, which measures the effect of removing an observation; Helsel and Hirsch, 2002) (fig. 5). When this sample was omitted from the regression, both the slope and intercept changed considerably (table 1, model 2), and the fit improved for samples at the lower end of the concentration range. Omitting this sample from the regression, however, limits use of the equation to $\mathrm{SC}$ values less than $25,700 \mu \mathrm{S} / \mathrm{cm}$ (the second greatest value in the dataset). The July 10, 2013, sample was accurately measured during an extremely dry year when discharge in the river fell below $0.01 \mathrm{ft}^{3} / \mathrm{s}$ for several weeks in June and July. Although such dry periods are relatively rare, the daily mean $\mathrm{SC}$ at this site also exceeded $25,700 \mu \mathrm{S} / \mathrm{cm}$ during the summers of $1981,1982,2002$, and 2013 for a total of 51 days over the period of record. To better accommodate the entire range of concentrations, a second-order polynomial was fit to the complete dataset with a coefficient of determination $\left(\mathrm{R}^{2}\right)$ of 0.999 (table 2, model 3). Although the relation between TDS and SC is approximately linear at low to moderate concentrations, the relation becomes increasingly curvilinear at higher concentrations (Hem, 1985), which is consistent with the observed data for the downstream site. In model 3, the y-intercept was fixed at zero to improve the fit for samples at the low end of the concentration range and because pure water has a conductance less than $1 \mu \mathrm{S} / \mathrm{cm}$. The plot of residual TDS (observed minus predicted values) versus the predicted TDS concentrations (fig. $6 \mathrm{~A}$ ) illustrates heteroscedasticity because the magnitude of error in the predicted TDS is correlated with the value of predicted TDS. Heteroscedasticity often occurs when there is a wide range between the lowest and greatest values, as is the case for the downstream site where $\mathrm{SC}$ varies by nearly three orders of magnitude (note log scale in fig. $6 A$ ). Figure $6 A$ also shows that the greatest residuals occur in samples with elevated sulfate concentrations and $\mathrm{SC}$ values in the $1,500-3,000 \mu \mathrm{S} / \mathrm{cm}$ range. Increasing the sulfate-to-chloride ratio in solution will increase the slope of the TDS to SC relation, which is why the regression underestimated TDS for samples with elevated sulfate. The high-sulfate samples accounted for less than 5 percent of the discrete water-quality samples, and nearly all were collected during short-duration storm events in July through October. Given the intermittent nature of these events and the lack of detailed water-quality data during storms, it would be impractical to capture this level of variability in the regression model at this site.

For the upstream station, the fit of the linear model (table 2, model 4) is not as strong $\left(\mathrm{R}^{2}=0.924\right)$ as the linear fit for the downstream site because a group of samples with sulfate concentrations over $500 \mathrm{mg} / \mathrm{L}$ causes the values to diverge at the high end of the concentration range (fig. 7). As shown by the model 4 fit (dashed blue line in fig. 7), the high sulfate samples leverage the regression line upwards, which degrades the fit for low-concentration samples. Samples with

Table 2. Parameters and coefficients of determination of regression models used to estimate total dissolved solids concentrations from specific conductance for the Dolores River at Bedrock site (upstream site) and the Dolores River near Bedrock site (downstream site).

[95\% CI, 95 percent confidence interval; $\mathrm{SC}^{2}$, coefficient for squared specific conductance term; n, number of samples; $\mathrm{R}^{2}$, coefficient of determination; Std. error, residual standard error in milligrams per liter; P, p-value; --, not used in model; <, less than]

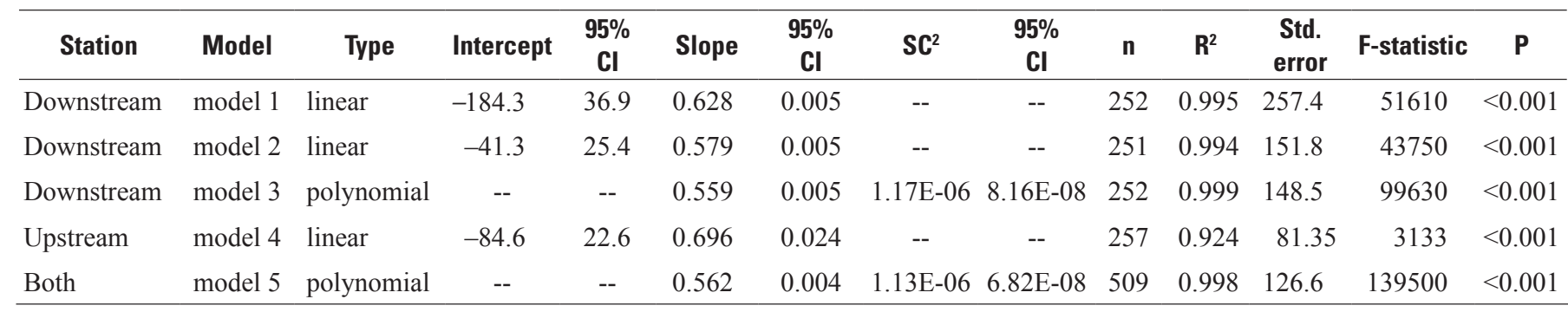




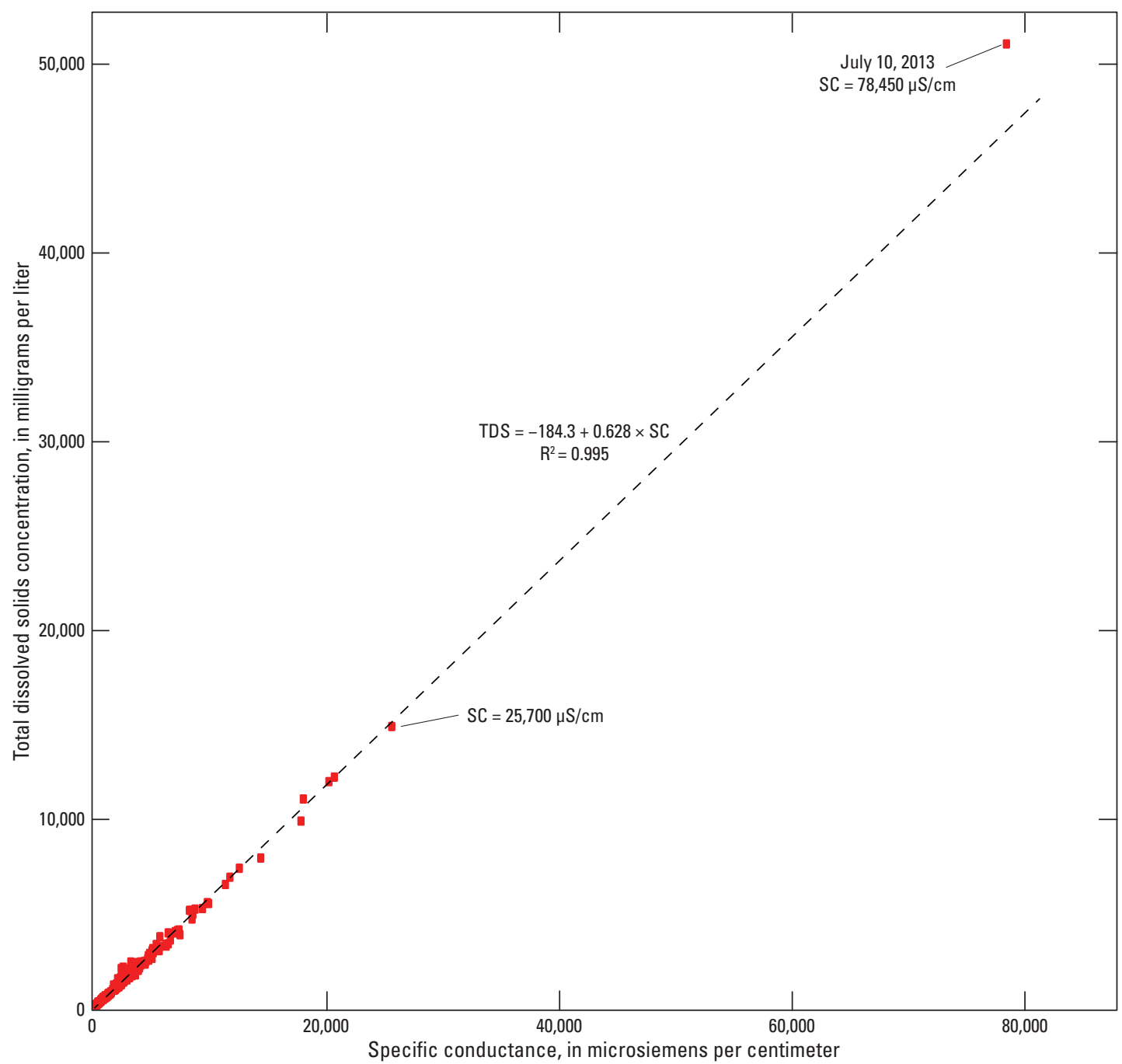

Figure 5. Specific conductance (SC) versus total dissolved solids (TDS) concentrations in 252 waterquality samples collected at the Dolores River near Bedrock site (downstream site) during 1987-2015. Sample collected on July 10, 2013, occurred during an exceptionally dry period when streamflow fell to the lowest level on record. Regression equation is model 1 in table 2. ( ${ }^{2}$, coefficient of determination) 


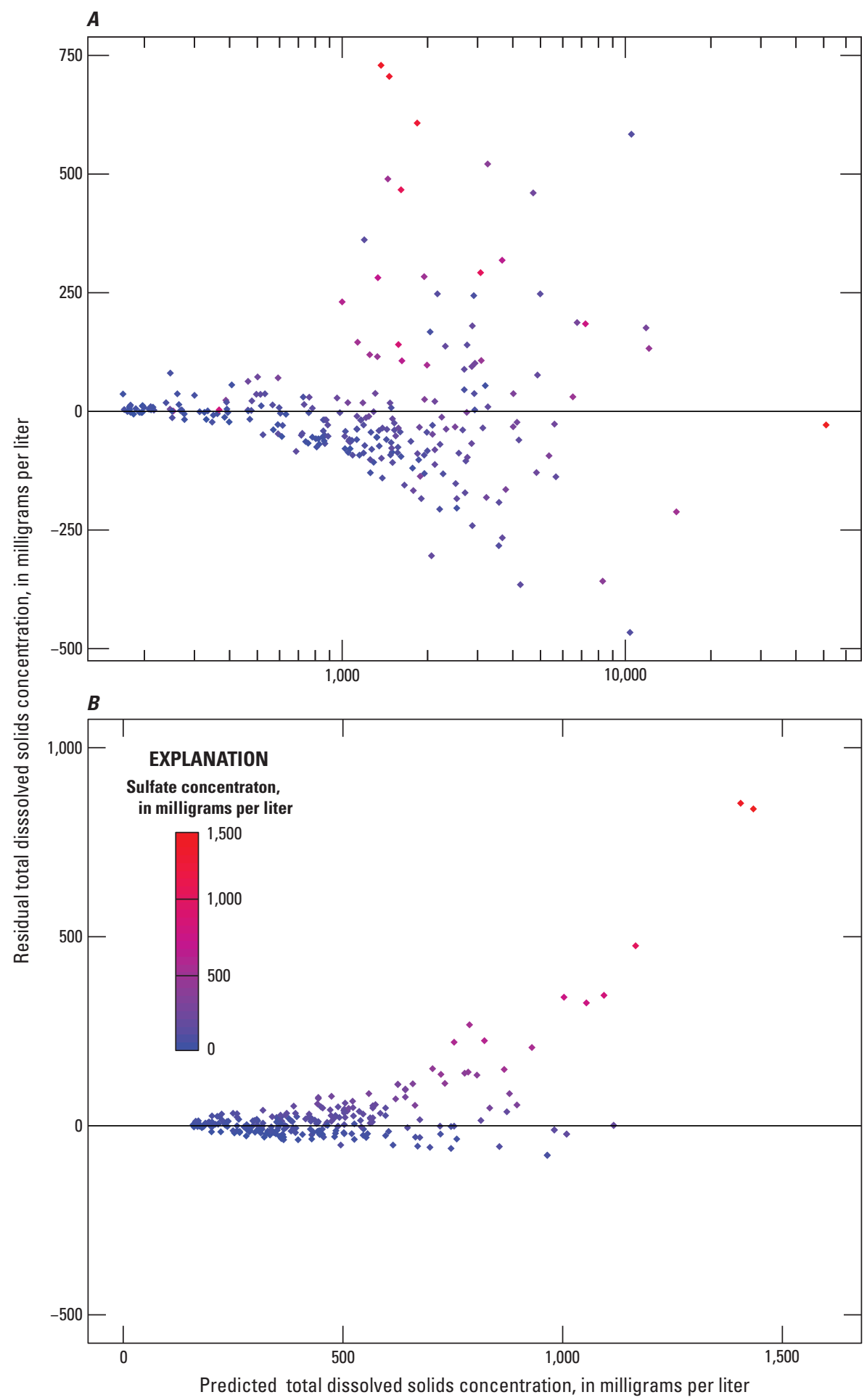

Figure 6. Predicted versus residual (observed - predicted) total dissolved solids concentrations using model 3 for $(A)$ the Dolores near Bedrock site (downstream site) and model 5 for $(B)$ the Dolores at Bedrock site (upstream site). Colors represent range of sulfate concentrations in water-quality samples. 


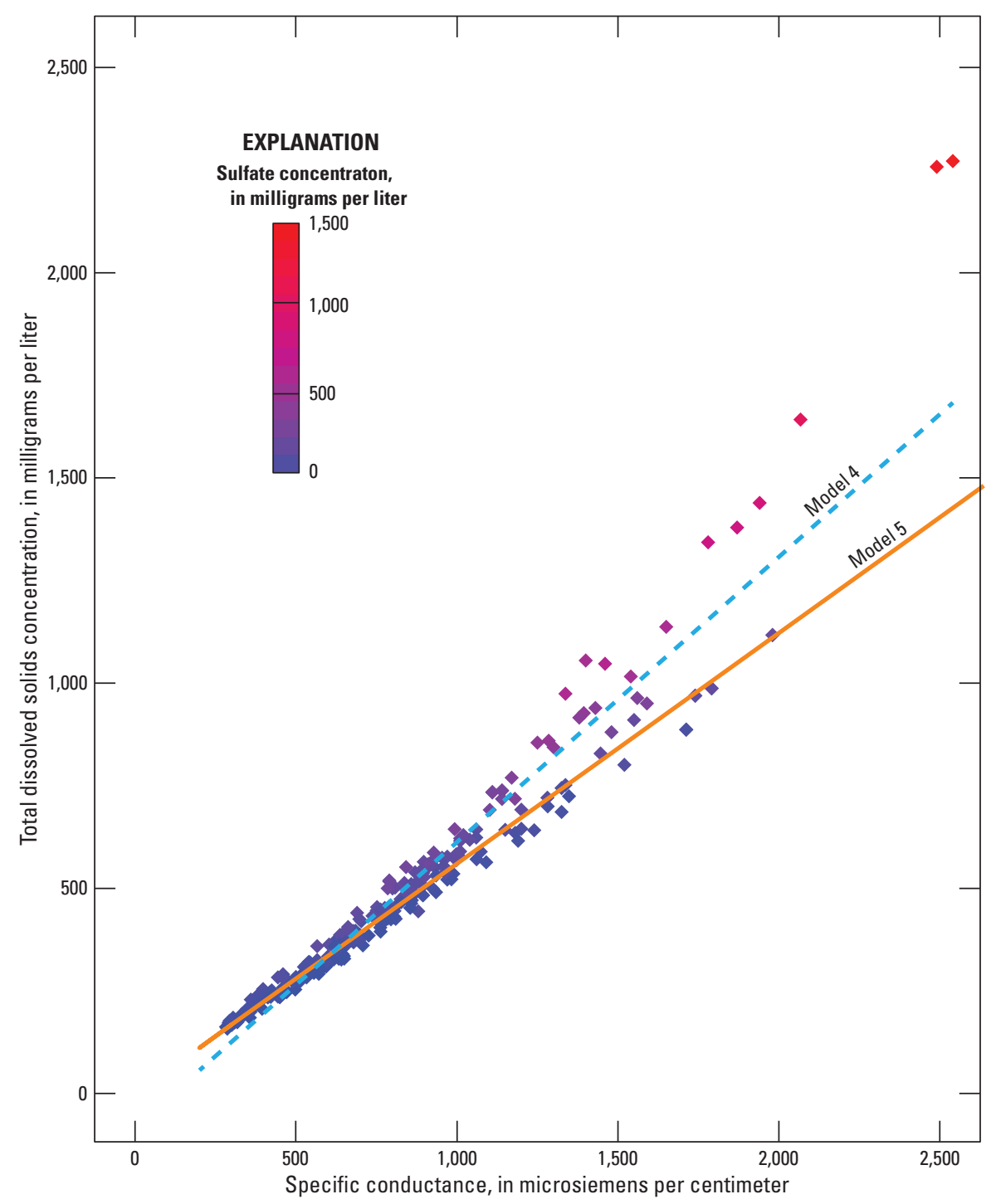

Figure 7. Specific conductance versus total dissolved solids concentrations for the Dolores River at Bedrock site (upstream site). Model 4 is a linear fit of data from the upstream site, and model 5 is a polynomial fit of data from both the upstream and downstream sites (see table 2). Colors represent range of sulfate concentrations in water-quality samples.

elevated sulfate, as observed at the downstream site, typically are associated with storm events in late summer and fall. Samples in the same SC range but with lower sulfate concentrations fall in line with a polynomial model fit to combined data from both the upstream and downstream sites (fig. 7 and table 2, model 5). Because high-sulfate samples account for a small fraction of samples collected, the combined-site polynomial model (table 2, model 5) may be more appropriate than the single-site linear model (table 2, model 4) for estimating TDS at the upstream site. Indeed, the residual plot in figure $6 B$ shows that the polynomial model does a good job of estimating TDS over the entire range of samples, with the exception of samples with elevated sulfate. However, because sulfate concentrations typically are elevated at both stream sites during storm events, any bias introduced by the regression may be similar at both sites and likely has minimal effect on the net salt load during those events. The polynomial models, therefore, provide the best fit for predicting TDS over a wide range of concentrations at both sites.

To test whether the relation between TDS and SC has changed over time, linear models were fit for the pre-PVU period (1987-1993), the entire post-PVU period (1997-2015), and two subdivisions of the post-PVU period (1997-2006 and 2007-2015). The outlier at the downstream site from July 10 , 2013, was excluded from this analysis to avoid biasing the regression for any test period that included this sample. All data at the upstream site were retained for this analysis. Figure 8 compares the slope and intercept for each time 

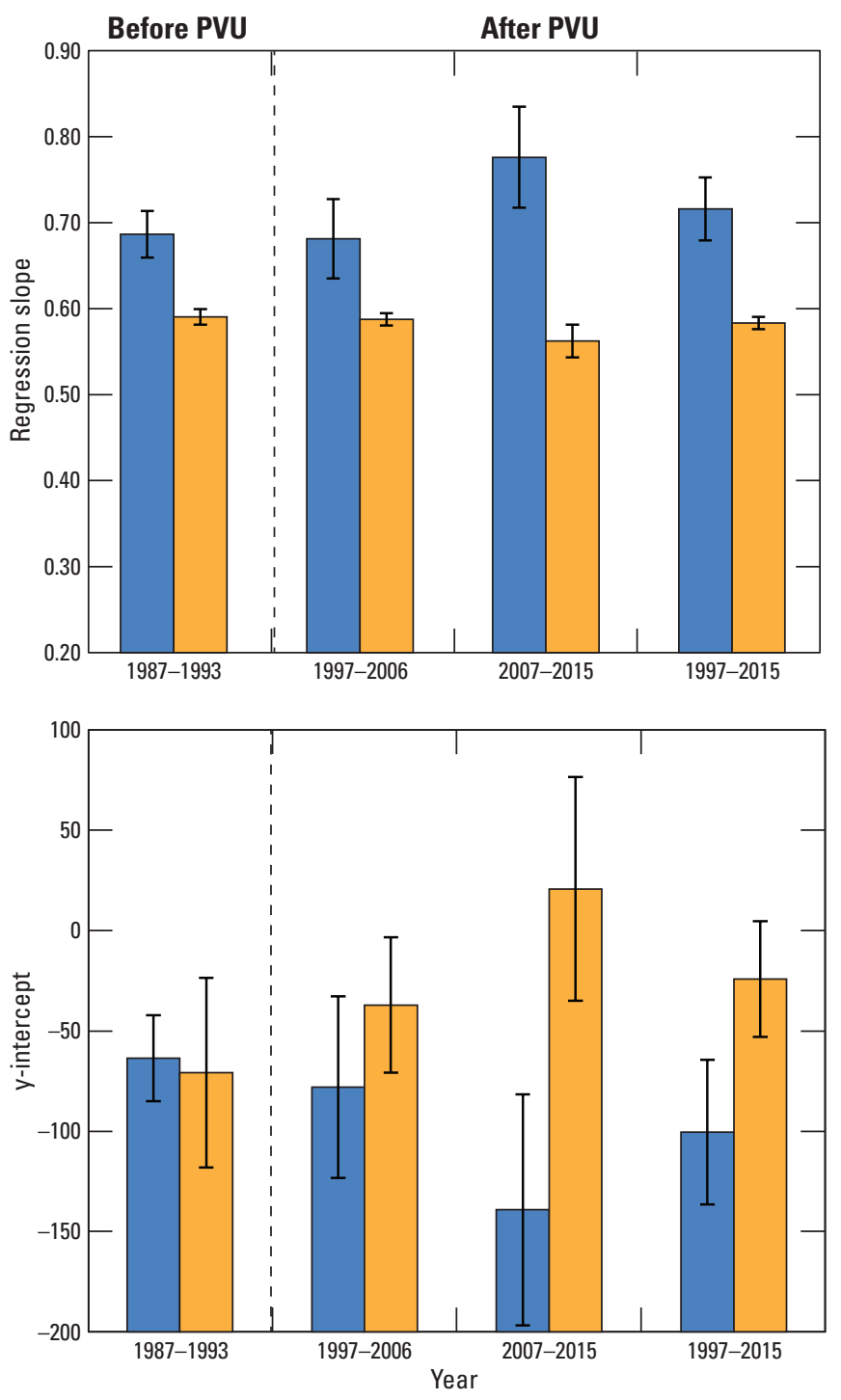

\section{EXPLANATION}

Upstream site

Downstream site

Figure 8. Comparison of slope and y-intercept resulting from linear fit of total dissolved solids concentrations with specific conductance for the Dolores River at Bedrock site (upstream site) and the Dolores River near Bedrock site (downstream site) for periods before and after operation of the Paradox Valley Unit (PVU) began. Error bars represent 95 percent confidence intervals for each regression coefficient.

period, with error bars showing the 95 percent confidence intervals of each coefficient. Although the coefficients differ among the pre- and post-PVU periods, the 95 percent confidence intervals overlap for all four time periods, suggesting that the relation between TDS and SC has not changed substantially over time. There appears to be more variability in the y-intercept than the slope, which may reflect differences in the concentration ranges of the four time periods and, in particular, greater influence (or leverage) of high-concentration samples on the regression. If the y-intercept is set to zero, the linear-regression slopes for the downstream site are essentially identical between the pre-PVU period (slope $=0.574)$ and the post-PVU periods (slope $=0.573$ ), suggesting that a single regression equation adequately represents the entire period of record.

\section{Annual Salt Loads for the Dolores River}

Based on the regression statistics (table 2) and residual plots presented in the previous section, model 5 was selected to estimate daily mean TDS at both the upstream and downstream sites. Daily loads were computed as the product of daily mean discharge and daily mean TDS (see "Data Analysis" section). Salt gain through the Paradox Valley was estimated as the load at the downstream site minus the load at the upstream site. A plot of daily salt gain for 2015 shows that the majority of the salt gain to the river occurs during winter and early spring (fig. 9). Although most days show large gains, there typically are several days each year with apparent losses (fig. 9). Negative values of daily salt gain often occur during short-duration discharge events, particularly in summer and fall, because of time lags in peak runoff between the upstream and downstream sites (for example, October 22-23 in fig. 9). Apparent salt losses also might result from measurement uncertainty, bias in the regression model, and (or) error associated with estimated SC records.

The computed annual salt load at both Dolores River sites and the annual salt gain through the Paradox Valley are tabulated with uncertainties in table 3 . Annual salt gain computed in this study is plotted alongside values estimated using previously developed regression equations (U.S. Geological Survey, 2010) in figure 10. In this study, salt gain was computed back to 1980 , whereas the U.S. Geological Survey's earlier study (2010) only included data back to 1988 . The earlier period was not included in the earlier study because the SC monitor at the downstream site was moved in 1988. In this study, the periods 1980-1987 and 1988-2015 were deemed comparable based on data from a nearby SC sensor operated by Reclamation. Salt gain was not computed for 1986-87 because of large data gaps during those 2 years. For 1988-2010, salt gains estimated by the U.S. Geological Survey (2010) average 4 percent less than those computed in this study but are within the \pm 15 percent average uncertainty estimate of this study. This small bias may be due to differences in the regression models but perhaps also differences in how periods of missing record were estimated.

Although routine operation of the PVU production wells did not begin until July 1996, some brine was removed intermittently during 1991-1995 for testing of the injection well (table 3). Because brine removal during the first 3 years of testing was minimal (less than 4 percent of the annual salt load in the river), these years were included in the pre-PVU period, defined as 1980-1993. Routine pumping did not begin until midway through 1996, so the post-PVU period 


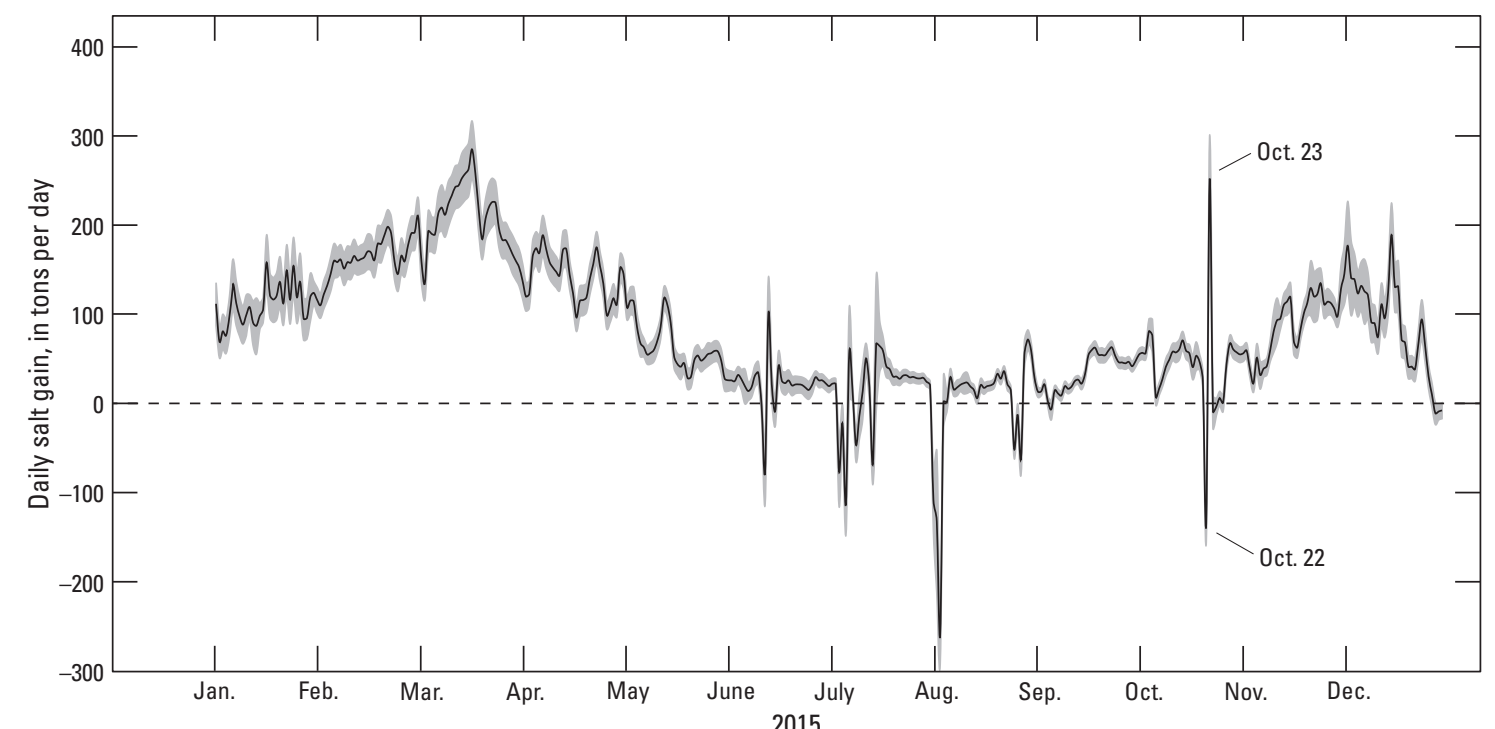

(gray) for the Dolores River through the Paradox Valley during 2015.

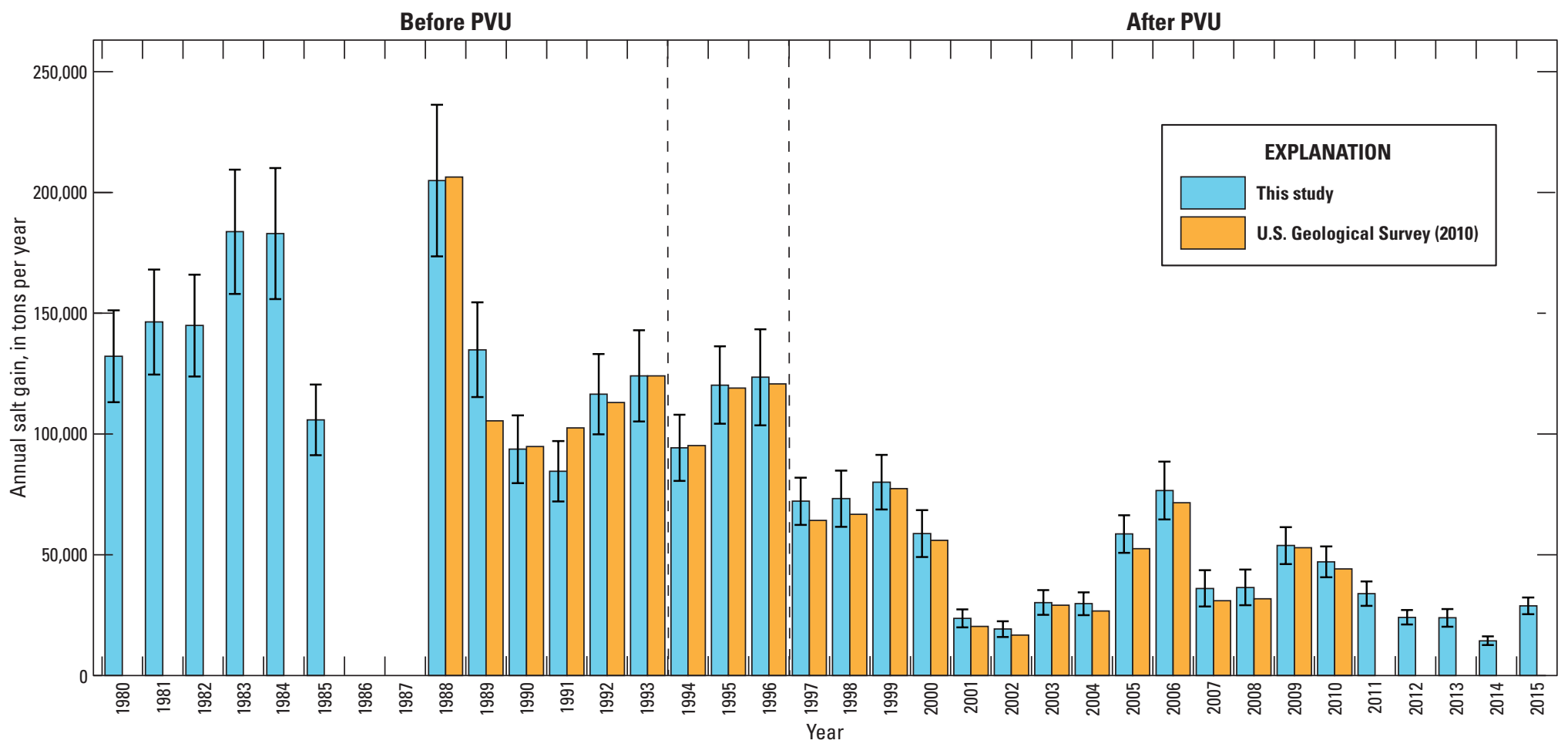

Figure 10. Annual salt gain in the Dolores River through the Paradox Valley with error bars showing measurement uncertainty for periods before and after operation of the Paradox Valley Unit (PVU) began (separated by vertical lines). Annual salt gains reported in the earlier study (U.S. Geological Survey, 2010) are included for comparison. 
Table 3. Annual salt removal by the Paradox Valley Unit (PVU), salt loads with uncertainty estimates for the Dolores River at Bedrock site (upstream site) and the Dolores River near Bedrock site (downstream site), and net salt gain through the Paradox Valley for 1980-2015.

[tons/yr, tons per year; net salt gain is load at downstream site minus load at upstream site; --, insufficient data, *, salt removal during testing of PVU injection well]

\begin{tabular}{|c|c|c|c|c|c|c|c|}
\hline \multirow[b]{2}{*}{ Year } & \multirow{2}{*}{$\begin{array}{c}\text { PVU } \\
\text { salt removal } \\
\begin{array}{c}\text { Load } \\
\text { tons/yr }\end{array}\end{array}$} & \multicolumn{2}{|c|}{ Dolores River at Bedrock } & \multicolumn{2}{|c|}{ Dolores River near Bedrock } & \multicolumn{2}{|c|}{ Net salt gain } \\
\hline & & $\begin{array}{l}\text { Load } \\
\text { tons/yr }\end{array}$ & $\begin{array}{l}\text { Uncertainty } \\
\pm \text { tons/yr }\end{array}$ & $\begin{array}{l}\text { Load } \\
\text { tons/yr }\end{array}$ & $\begin{array}{l}\text { Uncertainty } \\
\pm \text { tons/yr }\end{array}$ & $\begin{array}{l}\text { Load } \\
\text { tons/yr }\end{array}$ & $\begin{array}{l}\text { Uncertainty } \\
\pm \text { tons/yr }\end{array}$ \\
\hline 1980 & -- & 139,030 & 13,230 & 271,220 & 29,300 & 132,190 & 19,030 \\
\hline 1981 & -- & 43,800 & 4,500 & 190,210 & 20,400 & 146,410 & 21,740 \\
\hline 1982 & -- & 93,920 & 9,300 & 238,850 & 25,490 & 144,930 & 21,100 \\
\hline 1983 & -- & 196,480 & 18,330 & 380,250 & 39,640 & 183,770 & 25,710 \\
\hline 1984 & -- & 185,330 & 18,500 & 368,390 & 40,320 & 183,060 & 27,120 \\
\hline 1985 & -- & 176,950 & 17,480 & 282,870 & 27,400 & 105,920 & 14,650 \\
\hline 1986 & -- & 151,920 & 14,780 & -- & -- & -- & -- \\
\hline 1987 & -- & -- & -- & -- & -- & -- & -- \\
\hline 1988 & -- & 64,540 & 7,400 & 269,500 & 27,290 & 204,960 & 31,350 \\
\hline 1989 & -- & 56,040 & 6,070 & 190,980 & 18,390 & 134,940 & 19,560 \\
\hline 1990 & -- & 22,350 & 2,410 & 116,130 & 12,060 & 93,780 & 14,040 \\
\hline 1991 & $4,750^{*}$ & 39,430 & 4,340 & 124,040 & 12,280 & 84,610 & 12,530 \\
\hline 1992 & $7,090^{*}$ & 75,270 & 8,360 & 191,790 & 17,240 & 116,520 & 16,650 \\
\hline 1993 & $11,110^{*}$ & 134,710 & 17,390 & 258,840 & 20,820 & 124,130 & 18,880 \\
\hline 1994 & $61,960^{*}$ & 57,900 & 6,690 & 152,210 & 13,530 & 94,310 & 13,750 \\
\hline 1995 & $26,100^{*}$ & 104,450 & 8,690 & 224,730 & 23,300 & 120,280 & 15,990 \\
\hline 1996 & 33,730 & 32,270 & 3,270 & 155,780 & 19,420 & 123,510 & 19,840 \\
\hline 1997 & 97,030 & 143,010 & 14,450 & 215,210 & 19,620 & 72,200 & 9,830 \\
\hline 1998 & 125,970 & 91,860 & 10,520 & 165,140 & 18,040 & 73,280 & 11,600 \\
\hline 1999 & 112,970 & 65,370 & 6,870 & 145,470 & 13,850 & 80,100 & 11,360 \\
\hline 2000 & 85,230 & 43,370 & 5,450 & 102,240 & 10,890 & 58,870 & 9,700 \\
\hline 2001 & 75,620 & 31,150 & 3,360 & 54,840 & 6,350 & 23,690 & 3,750 \\
\hline 2002 & 111,810 & 14,970 & 1,960 & 34,260 & 3,760 & 19,290 & 3,300 \\
\hline 2003 & 112,700 & 23,410 & 2,720 & 53,660 & 6,610 & 30,250 & 5,120 \\
\hline 2004 & 103,040 & 29,270 & 3,140 & 59,100 & 6,880 & 29,830 & 4,720 \\
\hline 2005 & 101,580 & 94,860 & 8,580 & 153,510 & 14,870 & 58,650 & 7,770 \\
\hline 2006 & 101,700 & 42,780 & 5,480 & 119,440 & 10,690 & 76,660 & 11,980 \\
\hline 2007 & 113,460 & 44,810 & 8,020 & 80,960 & 8,490 & 36,150 & 7,500 \\
\hline 2008 & 111,450 & 74,670 & 12,410 & 111,190 & 12,890 & 36,520 & 7,400 \\
\hline 2009 & 104,850 & 35,380 & 3,370 & 89,230 & 9,340 & 53,850 & 7,620 \\
\hline 2010 & 111,910 & 42,330 & 3,620 & 89,450 & 9,340 & 47,120 & 6,360 \\
\hline 2011 & 111,910 & 41,510 & 4,050 & 75,490 & 8,520 & 33,980 & 5,070 \\
\hline 2012 & 112,690 & 24,630 & 1,710 & 48,820 & 4,930 & 24,190 & 2,960 \\
\hline 2013 & 81,020 & 25,690 & 2,420 & 49,610 & 6,130 & 23,920 & 3,720 \\
\hline 2014 & 100,940 & 28,240 & 2,020 & 42,720 & 4,250 & 14,480 & 1,770 \\
\hline 2015 & 100,310 & 29,860 & 2,060 & 58,810 & 5,750 & 28,950 & 3,460 \\
\hline
\end{tabular}


Table 4. Comparison of mean annual salt gain in tons per year in the Dolores River through the Paradox Valley before and after operation of the Paradox Valley Unit (PVU) began. Adjusted salt gains are based on the regression equation in figure 13. Salt disposal (tons per year) is the average annual salt injected through the PVU injection well during 1997-2015.

\begin{tabular}{lccc}
\hline & $\begin{array}{c}\text { Measured } \\
\mathbf{1 9 8 0 - 1 9 9 3}\end{array}$ & $\begin{array}{c}\text { Measured } \\
\mathbf{1 9 8 8 - 1 9 9 6}\end{array}$ & $\begin{array}{c}\text { Adjusted } \\
\mathbf{1 9 9 7 - 2 0 1 5}\end{array}$ \\
\hline Salt load in river before PVU & $137,900 \pm 20,200^{\mathrm{a}}$ & $121,900 \pm 18,100^{\mathrm{a}}$ & $123,800 \pm 21,700^{\mathrm{b}}$ \\
Salt load in river after PVU & $43,300 \pm 6,600^{\mathrm{a}}$ & $43,300 \pm 6,600^{\mathrm{a}}$ & $43,300 \pm 6,600^{\mathrm{a}}$ \\
Reduction in river salt load & $94,600 \pm 21,200$ & $83,200 \pm 19,900$ & $80,500 \pm 22,700$ \\
Salt disposal at PVU & $104,000 \pm 25,000^{\mathrm{c}}$ & $104,000 \pm 25,000^{\mathrm{c}}$ & $104,000 \pm 25,000^{\mathrm{c}}$ \\
\hline
\end{tabular}

${ }^{\mathrm{a}}$ Measurement uncertainty based on standard error propagation equation.

b95th percentile confidence interval for values predicted using regression equation in figure 13.

c95 percent confidence interval.

was defined as 1997-2015. The mean annual salt gain in the pre-PVU period was $137,900 \pm 20,200$ tons per year during 1980-1993 and 121,900 18,100 tons per year during $1988-$ 1996 (the period analyzed by U.S. Geological Survey [2010]) (table 4). The slightly greater salt gain estimated by this study for 1980-1993 may be caused by the wetter climatic conditions during the mid-1980s or exclusion of years during the testing period when some salt removal occurred; however, overlap in the uncertainty estimates suggests that measurement uncertainties also could explain this difference. After the PVU began operation (the post-PVU period), the mean annual salt gain in the river was reduced to $43,300 \pm 6,600$ tons per year (1997-2015), or about 70 percent less than the salt gain before the PVU began operation.

A potentially important question is whether direct comparison of salt gains in the pre- and post-PVU periods is appropriate given that mean annual discharge was significantly ( $<<0.001$ for Wilcoxon rank-sum test) less in the post-PVU period $\left(169 \mathrm{ft}^{3} / \mathrm{s}\right)$ compared to the pre-PVU period $\left(466 \mathrm{ft}^{3} / \mathrm{s}\right)$ (fig. 11). Declines in streamflow in the Dolores River were caused by flow regulation and diversion at the McPhee Reservoir (completed in 1984) as well as increasing periods of drought in the post-PVU period, as illustrated by the Palmer Drought Index (fig. 11) for the upper Colorado River Basin (National Oceanic and Atmospheric Administration, 2015). Some water also is removed from the system by the PVU production wells; however, the mean annual pumping rate of $0.5 \mathrm{ft}^{3} / \mathrm{s}$ is small relative to the change in river discharge between the pre- and post-PVU periods. Although the effect of declining river flows on brine discharge is unknown, the positive relation between annual salt gain and annual mean discharge (fig. 12) suggests that more brine is discharged to the river in wet years, perhaps because greater freshwater recharge to the alluvial aquifer enhances brine discharge into the river.

One approach to adjust salt loads for different flow conditions uses the relation between annual volume-weighted mean (VWM) TDS and annual mean discharge in the pre-PVU period (fig. 13). The VWM TDS for each year was computed as the sum of the daily TDS times daily discharge divided by the sum of the daily discharge. The relation between TDS and discharge is strong and shows a clear shift between the preand post-PVU periods (fig. 13). Using the pre-PVU model in figure 13, VWM TDS was predicted using annual discharge for each year during 1997-2015, and salt loads were adjusted for this drier period as if the PVU did not exist. The drought year 2002 was omitted because discharge was much less than in any year during the pre-PVU period. The salt gain for 1997-2015 was then recomputed from the difference between the adjusted load at the downstream site minus the measured load at the upstream site (fig. 14). This method yielded an adjusted annual salt gain of 123,800 tons per year for the drier 1997-2015 period, which is 10 percent less than the salt gain during the wetter 1980-1993 period. The absolute difference in salt gain between the wetter and drier periods was 14,100 tons per year, which was still within the uncertainty $( \pm 20,200$ tons per year) of the salt gain for the pre-PVU period.

Annual disposal of brine at the PVU ranged from 75,620 to 125,970 tons per year (table 3 ) and averaged 104,000 tons per year during 1997 to 2015 (table 4). The change in salt load in the river between the pre-PVU (19801993) and post-PVU (1997-2015) periods was 94,600 tons per year, comparing closely (within uncertainty) to the average annual salt disposal at the PVU (table 4). By using the shorter pre-PVU period (1988-1996), the apparent reduction in salt gain was 83,200 tons per year. The difference in these two estimates may be related to changes in streamflow, which declined between the pre- and post-PVU periods because of flow regulation at McPhee Reservoir and increasingly drier conditions. The adjusted average salt load, which accounts for the lower flow conditions of last two decades, is slightly lower at 123,800 tons per year (as described in the previous paragraph), suggesting that around 10 percent of the post-PVU period salt reduction might be due to decreased flow in the Dolores River. 


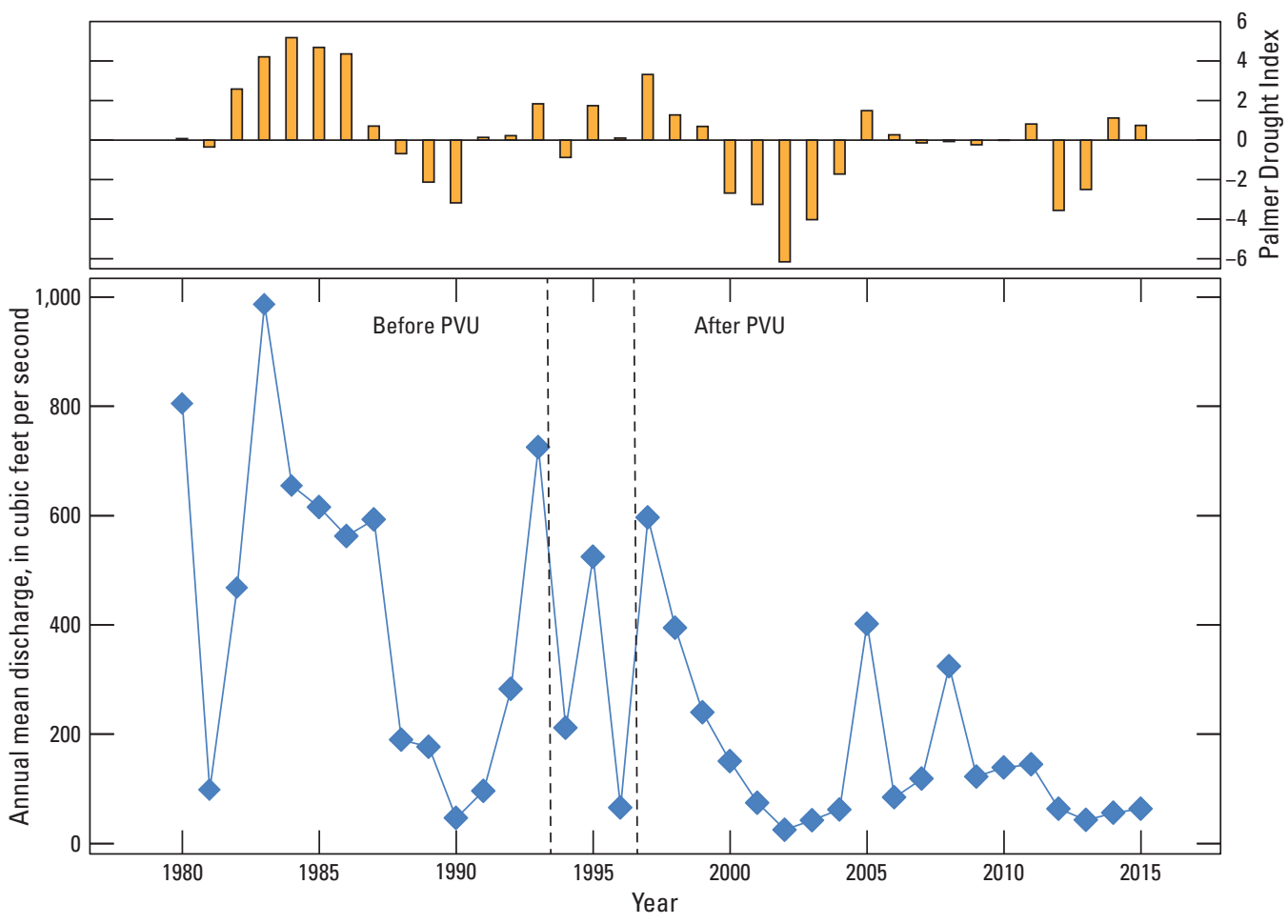

Figure 11. Annual mean discharge at the Dolores River near Bedrock site (downstream site) for periods before (1980-1993) and after (1997-2015) operation of the Paradox Valley Unit (PVU) began (separated by a vertical lines) with the annual Palmer Drought Index (PDI) for the upper Colorado River Basin. Negative values for the PDI indicate drought conditions.

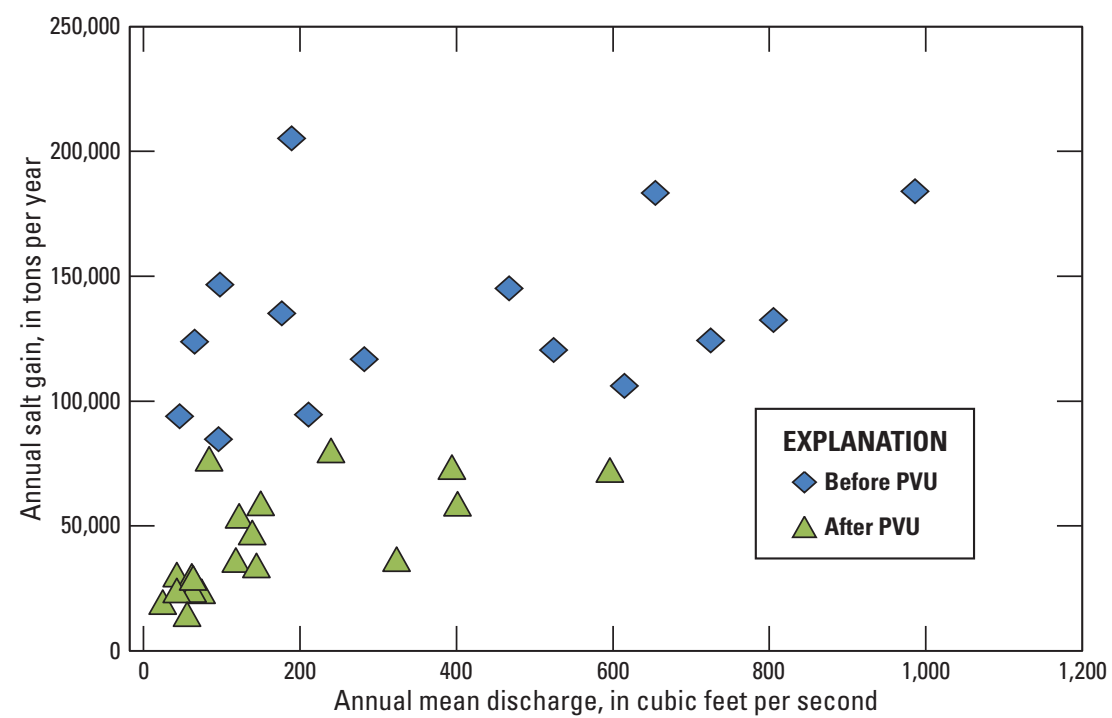

Figure 12. Annual mean discharge at the Dolores River near Bedrock site (downstream site) versus annual salt gain for periods before (1980-1993) and after (1997-2015) operation of the Paradox Valley Unit (PVU) began. 


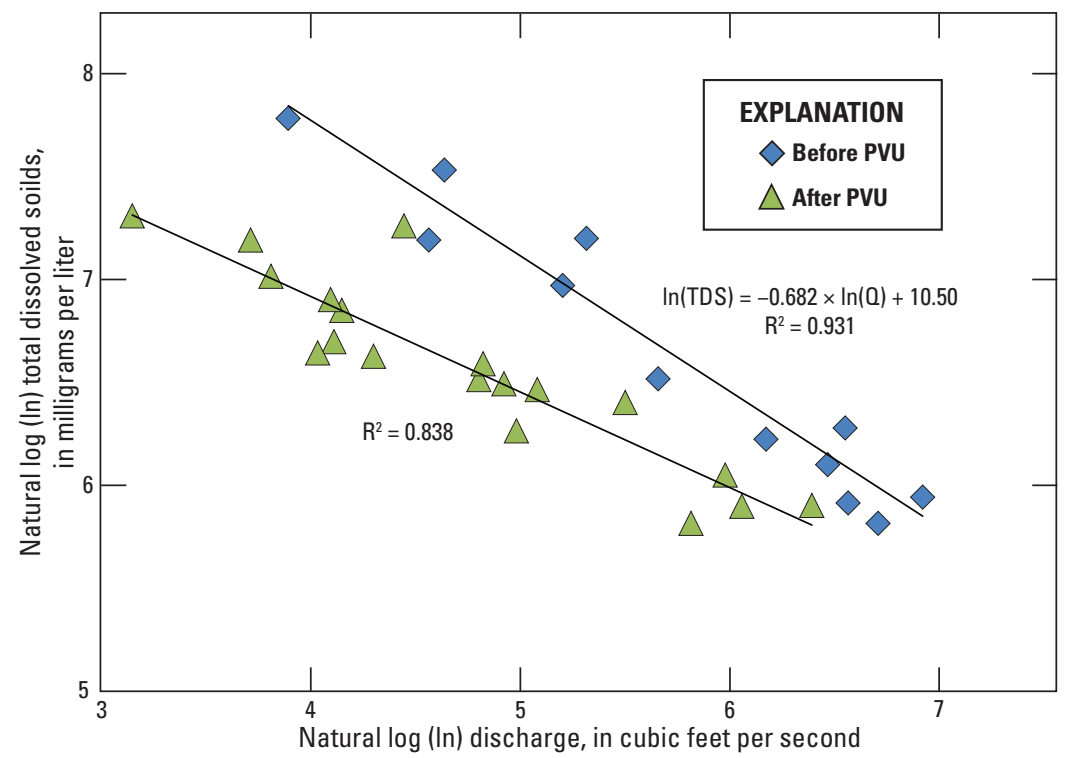

Figure 13. Annual mean discharge ( 0 ) versus volume-weighted mean total dissolved solids (TDS) concentrations for the Dolores River near Bedrock site (downstream site) for periods before (1980-1993) and after (1997-2015) operation of the Paradox Valley Unit (PVU) began. Data for 2002 not included in regression. ( $\mathrm{R}^{2}$, coefficient of determination)

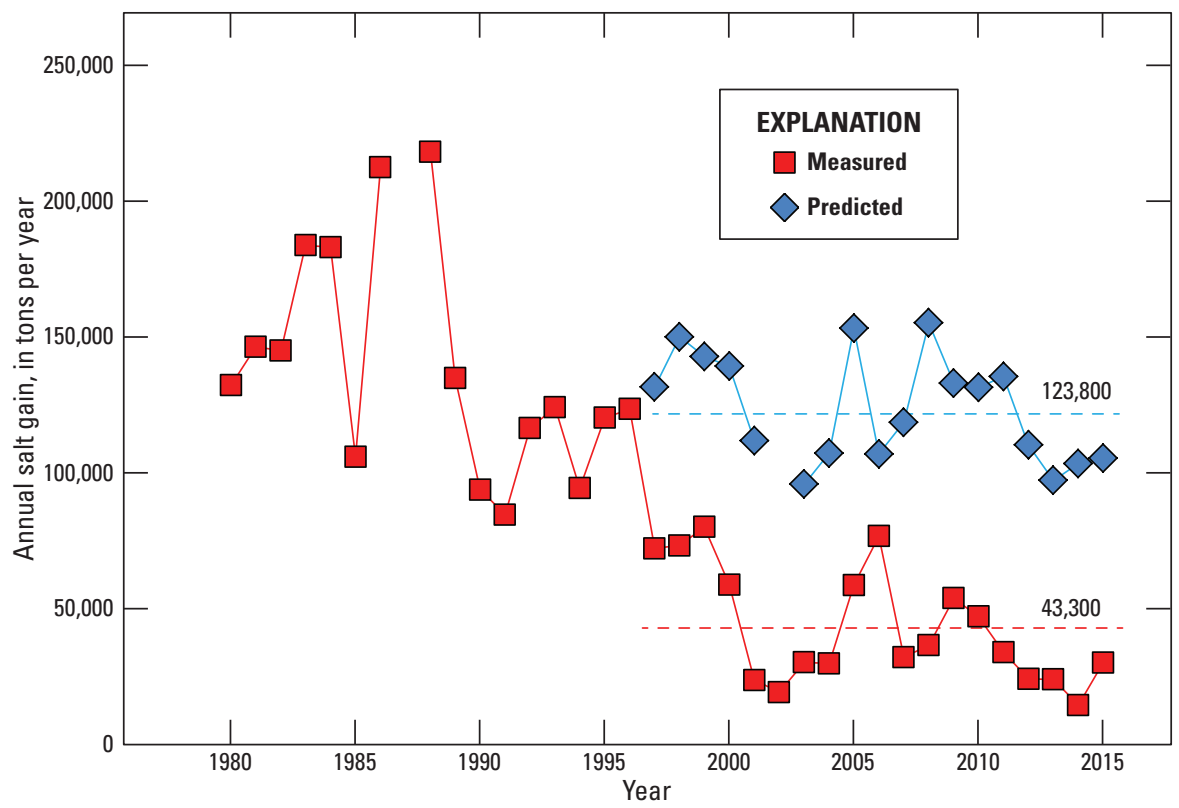

Figure 14. Annual salt gain in the Dolores River during 1980-2015. Predicted values derived from the relation between total dissolved solids and discharge before operation of the Paradox Valley Unit began (shown in figure 13). Data for 2002 not included in prediction. 


\section{Summary}

This report documents regression models developed to relate total dissolved solids (TDS) concentrations to specific conductance (SC) for the Dolores River at Bedrock site (USGS station 09169500) and the Dolores River near Bedrock site (USGS station 09171100) using available data through 2015. These results will be used to update the regression equations reported on the U.S. Geological Survey National Real-Time Water Quality website (http://nrtwq.usgs. gov/). Additionally, the regressions are applied to continuous records of SC to estimate the gain in salinity to the river as it flows across the Paradox Valley for 1980 through 2015.

The water quality of the Dolores River changes considerably as it crosses the Paradox Valley because naturally saline groundwater discharges into the river. For example, during an extremely dry period in June 2013, the conductance of the river increased over 30 -fold (1,990 to 31,000 microsiemens per centimeter) between the upstream and downstream sites. During the spring snowmelt period in April through June when streamflow is relatively high, major-ion concentrations at the downstream site approach those at the upstream site. During July through March, when streamflow is relatively low, brine discharge from groundwater has a greater influence on water-quality, and sodium and chloride dominate the major-ion composition at the downstream site with concentrations much greater than at the upstream site. Ranges of sulfate and calcium concentrations are fairly similar between the two sites during most months, suggesting that areas upstream of the valley as well as brine discharge are important sources of these solutes.

A second-order polynomial provided the best fit of TDS versus SC data for both the upstream and downstream sites. The largest residuals occurred in samples with elevated sulfate concentrations (greater than 500 milligrams per liter) that were associated with short-duration storm events in late summer and fall. Because sulfate concentrations often were elevated at both sites on the same sampling date, any bias introduced by the model likely has a negligible effect on the computed net salt load during those events. Regression models were compared between a period before operation of the Paradox Valley Unit (PVU) began (pre-PVU) and three periods after operation began (post-PVU) to test whether the relation had changed over time. Although regression coefficients are slightly different among the pre- and post-PVU periods, the 95 percent confidence intervals overlap for all four tested time periods, suggesting that the relation between TDS and SC has not changed significantly over time and that a single regression equation can be used for the entire period of record.

Salt gain through the Paradox Valley was estimated as the TDS load at the downstream site minus the load at the upstream site. The mean annual salt gain in the pre-PVU period (1980-1993) was 137,900 tons per year. After the PVU began operation (1997-2015), the salt gain in the river was reduced to 43,300 tons per year. The change in salt load in the river between the pre-PVU and post-PVU periods was 94,600 tons per year, which represents a nearly 70 percent reduction in salt loading to the river and compares closely to the average mass of salt (104,000 tons) disposed of each year at the PVU injection well. However, around 10 percent of this salt load reduction might be attributed to declining streamflow in the post-PVU period.

\section{References Cited}

Ball, L.B., Bloss, B.R., Bedrosian, P.A., Grauch, V.J.S., and Smith, B.D., 2015, Airborne electromagnetic and magnetic survey data of the Paradox and San Luis Valleys, Colorado: U.S. Geological Survey Open-File Report 2015-1024, 19 p.

Bureau of Reclamation, 1978, Colorado River Basin salinity control project_-Paradox Valley Unit definite plan report. Appendix B-Hydrosalinity: Bureau of Reclamation, Upper Colorado Region, 173 p., at https://www.usbr.gov/uc/wcao/ progact/paradox/DPR1978-Appdx-B.pdf.

Bureau of Reclamation, 1997, Paradox Valley Unit final supplemental definite plan report and environmental assessment: Bureau of Reclamation, Colorado River Basin Salinity Control Project, 211 p., accessed June 9, 2017, at https:// www.usbr.gov/uc/wcao/progact/paradox/SDPR-1997.pdf.

Cater, F.W., 1970, Geology of the salt anticline region in southwestern Colorado, with a section on Stratigraphy, by Fred W. Cater and Lawrence C. Craig: U.S. Geological Survey Professional Paper 637, $80 \mathrm{p}$.

Chafin, D.T., 2003, Effect of the Paradox Valley Unit on the dissolved-solids load of the Dolores River near Bedrock, Colorado, 1988-2001: U.S. Geological Survey WaterResources Investigations Report 02-4275, 6 p.

Fishman, M.J., and Friedman, L.C., eds., 1989, Methods for determination of inorganic substances in water and fluvial sediments: U.S. Geological Survey Techniques of Water Resources Investigations, book 5, chap. A1, 545 p.

Helsel, D.R., and Hirsch, R.M., 2002, Statistical methods in water resources: U.S. Geological Survey Techniques of Water Resources Investigations, book 4, chap. A3, 522 p.

Hem, J.D., 1985, Study and interpretation of the chemical characteristics of natural water: U.S. Geological Survey, Water-Supply Paper 2254, 263 p., 3 pls.

Katzenbach, M.S., 1990, Comparison of accuracy and completeness of data obtained from three types of automatic water-quality monitors: U.S. Geological Survey WaterResources Investigations Report 89-4198, 65 p.

Linard, J.I., and Schaffrath, K.R., 2014, Regression models for estimating salinity and selenium concentrations at selected sites in the Upper Colorado River Basin, Colorado, 2009-2012: U.S. Geological Survey Open-File Report 2014-1015, 28 p. 
Moncrieff, J.B., Malhi, Y., and Leuning, R., 1996, The propagation of errors in long-term measurements of landatmosphere fluxes of carbon and water: Global Change Biology, v. 2, p. 231-240.

National Oceanic and Atmospheric Administration, 2015, Climate Data Online [Colorado, 02 - CO Drainage Basin, 1980 to 2015, Palmer Drought Severity Index text output]: National Oceanic and Atmospheric Administration National Climatic Data Center database, accessed December 31, 2015, at https://www7.ncdc.noaa.gov/CDO/ CDODivisionalSelect.jsp.

Novak, C.E., 1985, WRD data reports preparation guide: U.S. Geological Survey Open-File Report 85-480, 323 p.

Taylor, J.R., 1997, An introduction to error analysis-The study of uncertainties in physical measurements ( $2 \mathrm{~d}$ ed.): Sausalito, Calif., University Science Books, 327 p.

Tuttle, M.L., and Grauch, R.I., 2009, Salinization of the upper Colorado River-Fingerprinting geologic salt sources: U.S. Geological Survey Scientific Investigations Report 20095072, 62 p.

U.S. Geological Survey, variously dated, National field manual for the collection of water-quality data: U.S. Geological Survey Techniques of Water-Resources Investigations, book 9, chaps. A1-A9.
U.S. Geological Survey, 2010, Estimates of dissolved-solids load of the Dolores River in the Paradox Valley, Montrose County, Colorado, 1988 through 2009: Bureau of Reclamation, prepared by U.S. Geological Survey [Administrative Report], 32 p., accessed April 18, 2017, at https://www.usbr. gov/uc/wcao/progact/paradox/RelatedDocs/ AdministrativeReport_ParadoxValley.pdf.

U.S. Geological Survey, 2015, USGS water data for the Nation: U.S. Geological Survey National Water Information System database, accessed November 30, 2015, at https:// doi.org/10.5066/F7P55KJN.

Wagner, R.J., Boulger, R.W., Jr., Oblinger, C.J., and Smith, B.A., 2006, Guidelines and standard procedures for continuous water-quality monitors-Station operation, record computation, and data reporting: U.S. Geological Survey Techniques and Methods, book 1, chap. D3, 51 p.

Watts, K.R., 2000, Effects of the Paradox Valley Unit on dissolved solids, sodium, and chloride in the Dolores River near Bedrock, Colorado, water years 1988-98: U.S. Geological Survey Water-Resources Investigations Report 00-4011, 8 p.

Publishing support provided by:

Denver Publishing Service Center

For more information concerning this publication, contact:

Director, USGS Colorado Water Science Center

Box 25046, Mail Stop 415

Denver, C0 80225

(303) 236-4882

Or visit the Colorado Water Science Center website at:

https://co.water.usgs.gov/ 

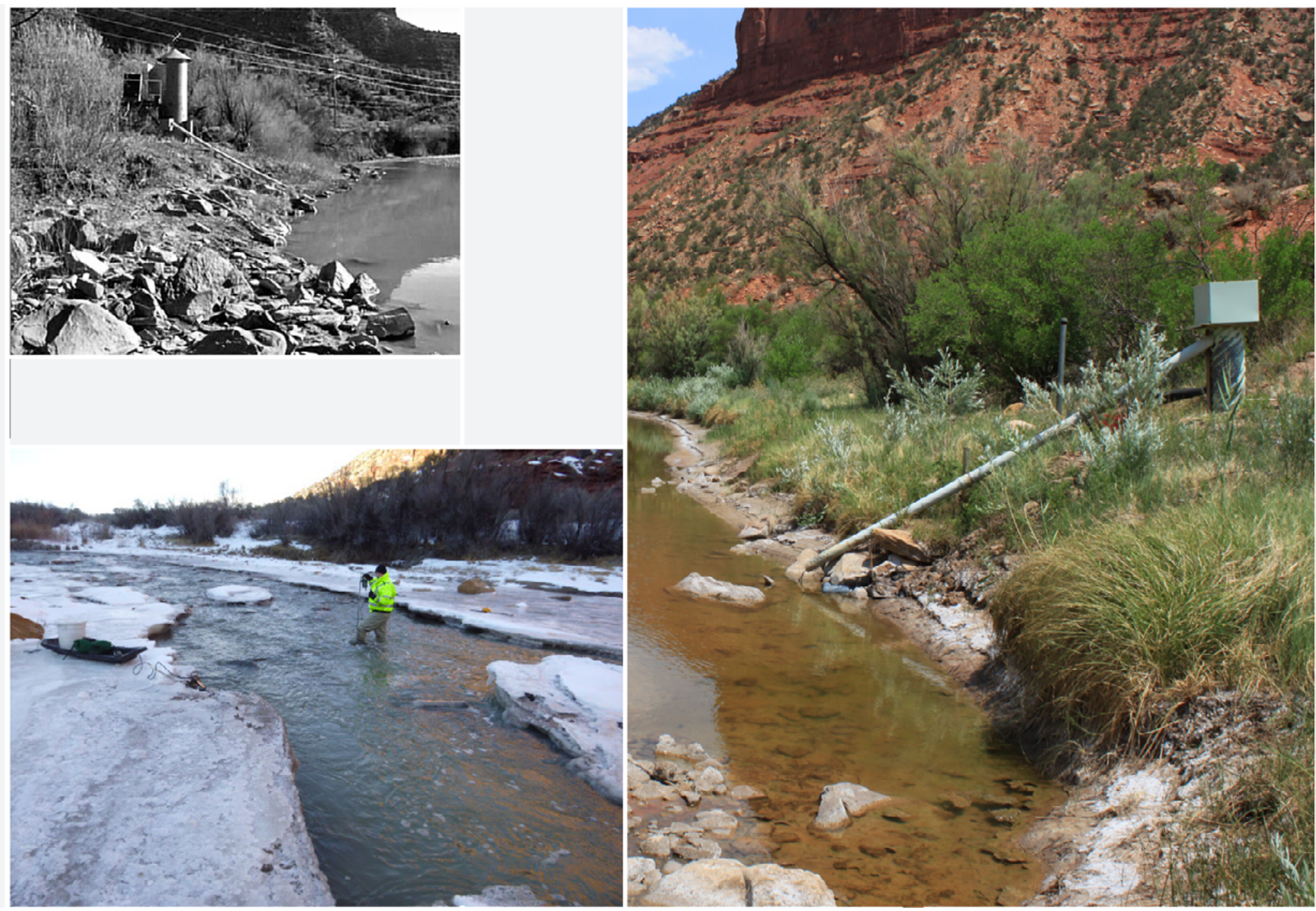

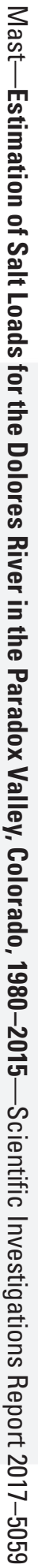

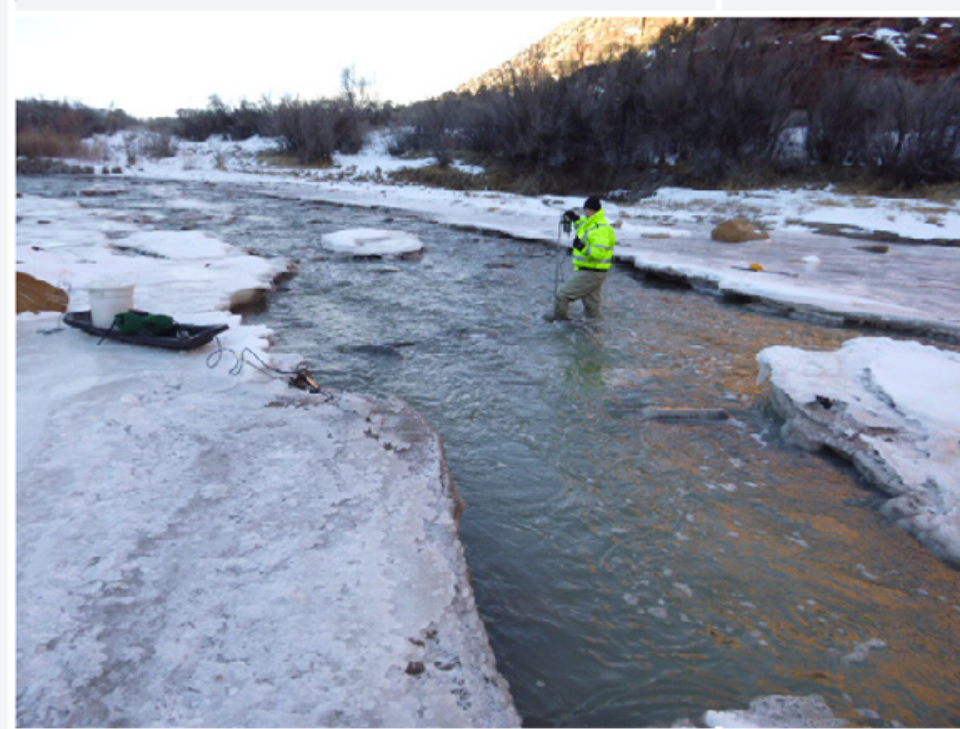

